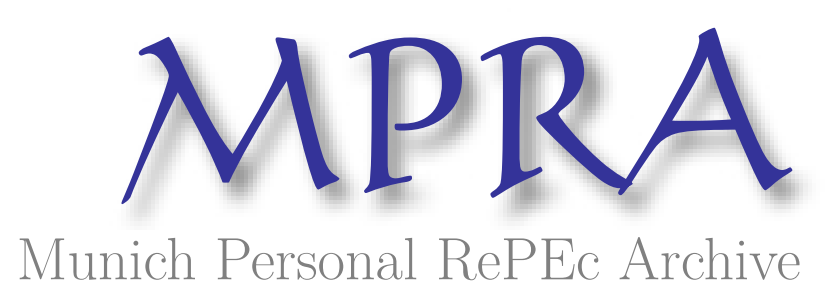

\title{
Corporate Social Responsibility: An Islamic Perspective
}

Elasrag, Hussein

5 May 2015

Online at https://mpra.ub.uni-muenchen.de/67537/

MPRA Paper No. 67537, posted 30 Oct 2015 21:11 UTC 


\section{Corporate social responsibility}

\section{An Islamic Perspective}

Hussein Elasrag 
Hussein Elasrag 
Copyright (C) 2015 Hussein Elasrag

All rights reserved.

ISBN: 1512034339

ISBN-13: 978-1512034332 



\section{CONTENTS}

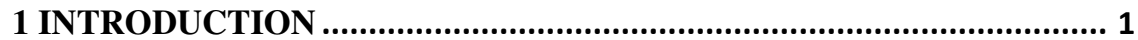

2 THE CONCEPT OF CORPORATE SOCIAL RESPONSIBILITY ......... 7

CORPORATE SOCIAL RESPONSIBILITY: DEFINITIONS AND HISTORY ................8

ISLAMIC CORPORATE SOCIAL RESPONSIBILITY ...........................22

THE CONCEPTS OF Business ETHICS AND CORPORATE SOCIAL

RESPONSIBILITY .......................................................................... 24

BENEFITS OF CORPORATE SOCIAL RESPONSIBILITY .................................... 32

3 THE BASIS FOR ISLAMIC SOCIAL RESPONSIBILITY ...................75

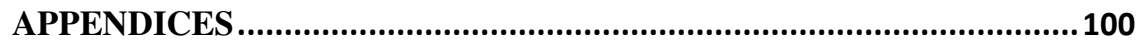

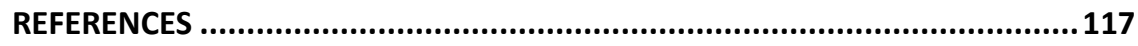


Hussein Elasrag 
Islam provides a basis and guideline for living one's life. Within this, there is a very detailed concept of ethical and social behaviour which allows us to deduce that the concept of social responsibility automatically has a role in Islam. This is a critical point that must be firstly understood as the role of moral ethics has been underpinned in Islam for over 1400 years whilst the concept of CSR remains relatively new for businesses today. The scope of this book is to briefly outline some of the major aspects of Islam which give consideration for businesses and their push towards Corporate Social Responsibility. It considers the belief system of Islam and how this belief has a significant underpinning of social behaviour. 



\section{INTRODUCTION}

Islam provides a basis and guideline for living one's life. Within this, there is a very detailed concept of ethical and social behaviour which allows us to deduce that the concept of social responsibility automatically has a role in Islam. This is a critical point that must be firstly understood as the role of moral ethics has been underpinned in Islam for over 1400 years whilst the concept of CSR remains relatively new for businesses today.

Corporate Social Responsibility (CSR) has been associated with related terms like business ethics, corporate performance, corporate accountability, corporate responsibility and stake holder involvement. In recent years CSR has grown into a well-known collective expression. The 
growth of CSR has been a result of organizations realizing their responsibility toward their stake holders in the context of business scandals (e.g. Enron) and a growing concern for environmental changes (e.g. global warming). ${ }^{1}$

The European Union defines CSR as "a concept whereby companies integrate social and environmental concerns in their business operations and in their interactions with their stakeholders on a voluntary basis" (European Commission, 2002). According to Vernon and Mackenzie (2007), the question of whether companies should seek to do good by exercising CSR, rather than concentrate solely on wealth creation, is no longer interesting and in fact the focus today is on how well companies do good. Increasingly stake holders expect companies to take on public responsibility. Companies engage in CSR through diverse activities such as donating to charitable organizations (e.g. Ben and Jerry's), 'green' activities (e.g. moves by major retailers to eliminate plastic bags and promote 'green' bags) and by implementing

1 Find out more from UK Essays here: http:/ / www.ukessays.com/dissertations/management/corporatesocial-responsibility.php\#ixzz3YECvtrHc 
Corporate social responsibility:An Islamic Perspective

environment friendly purchase and supply policies. A survey conducted by Research International, however, found that while CSR practices are commendable, they need to be viewed with caution as these activities are not sufficient in and of themselves (Social Funds, 2000).

Before going to understanding the concept Corporate Social Responsibility on Islamic perspective, we need to know the Islamic Worldview. Islam is a complete code of life. The fundamental of Islam such as aqidah,( belief and faith) ibadah (worship) and akhlaq (morality and ethics) are not subject to change, their manifestation in secondary areas like economics,

business and other worldly activities would require flexibility and development according to time and space. This is embodied in Islamic Shariah which is central to the worldview of Islam. Normally, the Shariah as Islamic Law, but the boundaries of Shariah extend beyond the limited horizons of law. The concept of CSR in Islam encompasses a broader meaning embracing the taqwa (God consciousness) dimension by which corporation as group of individual, assuming the roles and responsibility as servants and 
vicegerents in all situations(

The difference between Islam and most other religions is that it did not content itself with merely establishing acts of worship and abandon the needs of society to a Caesar or any form of temporal governing body. Rather, Islam established ways of conduct, relationships, and rights and obligations for the individual vis-à-vis members of his family and the nation and for the nation vis-à-vis other nations. The reform of society was the main target of Islam. Even acts of worship contribute to the achieving of this reform. Within the framework of human society, the Islamic nation is a compact union having recourse to itself, possessing an inner sense of responsibility for its own members, and resisting decay, both individually and collectively.

This social solidarity (takaful) is apparent in all aspects of Prophet Muhammad's Message. The history of mankind shows that few societies have developed as strong a sense of solidarity or have cooperated as closely or acted as mercifully as have Islamic societies.Developing this two-way responsibility is Islam's principal way of achieving reform 
and social solidarity. The individual's responsibility for the community in Islamic societies and conversely the community's responsibility for the individual are of primary magnitude, constituting a trust of life and the highest of its responsibilities. It is for that reason that Islam introduced community worship. Islam also enjoins the group not to neglect the individual, obligating it to safeguard his various interests, to respect his rights and freedom, and to harmonize different interests. In Islam, praying in groups is preferred many times over to praying individually. The individual is thus an integral element of the Islamic society; he perfects it and is perfected by it, he gives to it and receives from it and he protects it, and is protected by it. Developing this two-way responsibility is Islam's principal way of achieving reform and social solidarity. Islam has impressed the meaning of these two types of responsibility on the individual and collective conscience in order to guarantee for Muslims the life of a unified, sound, happy, and productive body in a classless community. ${ }^{2}$

\footnotetext{
2 See : Abd al-Rahman Azzam ,Social Responsibility in Islam(Part One), in: $\quad$ http://www.onislam.net/english/shariah/hadith/thishadith/456725-social-responsibility-in-islam-1.html
} 
The value of social responsibility, either individually or collectively, has been recognised throughout history, and more structured programs for endowments and zakat were introduced by Islam in the 7th century. Major organisations throughout the world now realise that corporate social responsibility (CSR) is an important part of a company's operations, because of its positive impact on society, which in turn impacts positively on staff members and the general public. $^{3}$

The scope of this book is to briefly outline some of the major aspects of Islam which give consideration for businesses and their push towards Corporate Social Responsibility. It considers the belief system of Islam and how this belief has a significant underpinning of social behaviour.

3 http://www.islamic-banking.com/csr.aspx 


\section{THE CONCEPT OF CORPORATE SOCIAL RESPONSIBILITY}

The field of corporate social responsibility (CSR) has grown exponentially in the last decade. More companies than ever before are engaged in serious efforts to define and integrate CSR into all aspects of their business, with their experiences being bolstered by a growing body of evidence that CSR has a positive impact on business economic performance. All of this is taking place against the backdrop of an ever more complex global economy with continuing economic, social and environmental inequities.

Most companies have considered social responsibility as a passive response to social pressure from the outside market. Now however, companies are positively responding to CSR demands. CSR is beginning to be incorporated into 
management processes in areas of investment, finance, and procurement. In other words, both the production process and the management process have become important factors in evaluating business, in addition to the more traditional factors of quality and cost of products. Further, because the power of choice that consumers and investors hold in the marketplace puts pressure on companies, this behavior serves as a message from the market, providing either positive or negative sanction. Comprehensive evaluations of corporate financial and non-financial value are developing in the market. The market is beginning to choose socially responsible and sustainable companies.(Tanimoto, 2007)

\section{Corporate Social Responsibility: Definitions}

\section{and History}

Corporate Social Responsibility (CSR) is a concept that 
Corporate social responsibility:An Islamic Perspective

has attracted worldwide attention and acquired a new resonance in the global economy. Heightened interest in CSR in recent years has stemmed from the advent of globalization and international trade 'which have reflected in increased business complexity and new demands for enhanced transparency and corporate citizenship. Moreover, while governments have traditionally assumed sole responsibility for the improvement of the living conditions of the population, society's needs have exceeded the capabilities of governments to fulfill them. In this context, the spotlight is increasingly turning to focus on the role of business in society and progressive companies are seeking to differentiate themselves through engagement in CSR. (Jamali \& Mirshak, 2007)

Corporate Social Responsibility CSR is an idea that has been constantly evolving as business firms are continually more aware of the community around them. CSR encompasses a business firm's obligation to society beyond simply maximizing its profits . CSR was not taken seriously and sometimes mocked by business firms before the late 1970s. The change in approach toward CSR can be partially attributed to the enactment of new legislation that created 
many of the regulatory government agencies during this time period. The new legislation provided business firms with an added incentive to earmark appropriate amounts of fiscal resources to CSR, rather than face harsh government regulation. The attitude toward CSR changed

drastically by the late 1990s, as CSR was now a mainstream idea being promoted by different facets of society, ranging from corporations to governments. (Brown, $\underline{2013})$

Corporate social responsibility (CSR) has grown enormously in the last thirty years and most business organizations feel to give in charity. The business organizations involving charitable giving and reflecting the highly competitive environment of the 1990s has been termed "strategic charity". It involves corporate giving which serves dual purposes: contributing funds to charitable causes while simultaneously benefiting the firm's financial bottom line and enhancing business political legitimacy. "Strategic charity" has become an accepted practice that allows a corporation to satisfy altruistic impulses to contribute in charitable causes while serving the bottom line. In this way the corporate community investment has 
Corporate social responsibility:An Islamic Perspective

emerged through the objectives of CSR programmes and business organizations some times take care of neighbor through its philanthropic responsibility programmes. Pure charity is concerned with assistance to education, arts and culture, health and social services, civic and community projects. While "strategic charity" combines pure philanthropy and business sponsorship with giving programmes that are directly or indirectly linked to business objectives. One of the characteristics of the "strategic charity" is a joint sponsorship of one or more corporations' programmes to implement through purposefully created charity foundations in order to optimize the charity value. (Hassan \& Latiff, 2009)

A significant number of terms and definitions are used, including; corporate responsibility, corporate accountability, corporate ethics, corporate citizenship, sustainability, stewardship, triple bottom line and responsible business. CSR could be defined as the voluntary integration of environmental, social and human rights considerations into business operations, over and above legal requirements and contractual obligations. CSR is the commitment of an 
organization to act in a manner that serves the interests of its stakeholders and is concerned with the ways that companies generate profits and their impact on the broader community. It is about how companies manage their business processes to produce an overall positive impact on society. McAlister (2005) and Carroll (1993) mentioned that there is a widespread acceptance of the view that if a business is to prosper, then the environment in which it operates must prosper as well. This means that business must adopt approaches in which companies see themselves as part of a wider social system.(Othman, 2009)

This responsibility is overwhelming and encompasses all aspects of a Muslim's life. It comprises a prescription towards positive (permissible and recommended) actions and a prescription against negative (impermissible and not recommended) actions. IFIs have generally ensured their operational status by avoiding negative actions. However, their approach to positive actions has been varied due to a lack of standards in the area. 
Corporate social responsibility:An Islamic Perspective

The combination of these principles denotes a divine accountability for each Muslim to enjoin good and justice and forbid evil and injustice. These core principles therefore constitute the basis of individual social responsibility.

Milton Friedman is one of the architects of the movement against social responsibility, writing what is considered by many the seminal piece of work disparaging CSR and the businesses who promoting their CSR credentials. Milton Friedman, 1962, 1982; Milton Friedman, September 13, $\underline{1970})$

Friedman's objection to CSR was two-fold.(Moon, 2011) First, he argued that managers were accountable to the owners of the business and that,unless they otherwise signalled, the assumption should be that the owners wanted the profits of the company to be maximised. The corollary is that for Friedman CSR is a net expenditure with no positive benefits for the company. Somewhat curiously, he added that it was possible for companies to make community investments but if these had some company advantages (e.g. workforce loyalty, productivity), they should not be considered as CSR. The conclusion here is that 
Friedman did not regard social and private Interests as potentially in conformance - rather they are dichotomous. This will betaken up later in the paper underthe heading, the 'socialisation of markets'.

Secondly, Friedman argued that CSR encroached on the proper terrain of (democratic) government and that managers are neither trained in addressing public policy questions and thus lack appropriate expertise, nor are they accountable for public policy issues. In both cases the contrast is made with legislators and public servants, both of whom he sees as having expertise and being properly accountable. In short, Friedman (1970) offers

another dichotomy, in this case between the work of government and the business of business.

According to Friedman (1970 cited in Galbreath 2009, p.111 ), it is the firm responsibility to meet the economic needs and that only leads to the welfare of the society and it is the role of the government, service organizations, educational institution to meet the societal welfare.

Galbreath, (2009) cited that after the publication of the thesis of Friedman, (1970) there was much research on the 
Corporate social responsibility:An Islamic Perspective social responsibilities of the firm. Galbreath, (2009) states that 'In the late 1970s, Carroll (1979) offered one of the first - and perhaps still the most widely accepted conceptualisations of CSR (Matten and Crane, 2005).' 4

In Galbreath (2009), Carroll's (1979) model conceptualises the responsibilities of the firm as:

1. The economic responsibility to generate profits;

2. the legal responsibility to comply by local, state, federal, and relevant international laws;

3. The ethical responsibility to meet other social expectations, not written as law (e.g. avoiding harm or social injury, respecting moral rights of individuals, doing what is right, just, fair); and

4. The discretionary responsibility to meet additional behaviours and activities that society finds desirable (e.g. philanthropic initiatives such as contributing money to various kinds of social or

4 Find out more from UK Essays here: http://www.ukessays.com/dissertations/sociology/corporate-socialresponsibility.php\#ixzz3YEAh6Nnb 
cultural enterprises).

Nowadays, companies have become more aware and mindful of their responsibilities, roles and rights towards the society. They are seen to have implemented activities, practices and guidelines in order to fulfill their legal, ethical, social and environmental responsibilities to stakeholders, which include shareholders, employees, customers, suppliers and the environment and society in general. These actions have been given many terms, including: (1) Corporate Responsibility or CR, (2) Corporate Social and Environmental Responsibility or CSER, (3) Corporate Citizenship, (4) Corporate Accountability, and lastly, Socially Responsible Business (SRB) (Raynard \& Forstater, 2002). However, the most famous terminology would have to be Corporate Social Responsibility or CSR.

CSR first began to be written about by academics in the 20th century. The term Corporate Social Responsibility and the modern view on CSR are largely attributed to Howard Bowen, who is considered by many scholars, especially Carroll, as the father of CSR. Bowen conceived CSR as an integral part of a larger vision of a better American society 
Corporate social responsibility:An Islamic Perspective

with a robust and socially responsible business sector. Before Bowen wrote his book in 1953, CSR was not a generally accepted practice among businesses in the United States. ${ }^{5}$

The business community needs to be aware of the responsibility it has towards the society. CSR does not mean just taking part in charitable activities and events, it means holding the responsibility to develop the society by envisioning future plans for socio-economic justice and be conscious about their responsibility for the welfare of society around them. The business community is highly qualified to set a plan for social change, and integrate their development goals with the country's at large, as well as engage with the other organisations on collaborative projects.

Islamic ethical principles provide a broader framework for CSR. In terms of responsibility and accountability, Muslims believe that they will be accounted for whatever they do in

5 Find out more from UK Essays here: http://www.ukessays.com/dissertations/management/corporatesocial-responsibility.php\#ixzz3YEFZUEdz 
this world in the hereafter (life after death). In Islam, Muslims verily have to fulfill the will of Allah in order to seek the promised rewards in the hereafter. Thus, it requires that every deed and word in this world must be in line with the Islamic teachings. The importance of accountability to the man's life also has been manifested by the Prophet Muhammad (PBUH) as "each one of you is a guardian and each guardian is accountable to everything under his care". Individuals are expected to feel socially responsible for others in the community. In general, the aim of the Islamic economic system is to allow people to earn their living in a fair and profitable way on the basis of Shariah without exploitation of others, so that the whole society may get benefits. Islam also emphasizes the welfare of the community over individual rights. (Shamim \& Karim, 2010)

CSR in the world view of Islam requires both individuals and organisations to be guided in the development of a moral self that distinguishes between right and wrong and never loses sight of its responsibilities towards God and mankind. Islam as a religion has not lost its general influence on societies where it is practiced and constitutes a 'complete 
Corporate social responsibility:An Islamic Perspective way of life' for the followers with specific implications for economic life and hence the role that responsible business can play in the development of a community/society/economy based upon the principles of social justice and equity rather than efficiency or profit generation. $^{6}$

Over the years, CSR has been developed from the classical 'profit-centred model' to the modern 'socially responsible model' (see Carroll (1999) for a comprehensive overview). The classical model states that the management's only legitimate goal is to maximize profit. Milton Friedman (1962), who has been recognized as an advocate of this view, believes that the primary responsibility of managers and directors is to operate in the best interests of the shareholders who are essentially the true owners of a corporation. The classical view perceives that corporate expenditure on social causes is a violation of management's responsibility to shareholders at least to the extent that these expenditures do not lead to higher shareholder wealth. On the other hand, Frank Abrams (1954) stated that a firm's

\footnotetext{
6 http://www.islamic-banking.com/csr.aspx
} 
management is responsible for maintaining an equitable and working balance among the claims of the various directly interested groups such as stockholders,employees, customers and the public at large. The World Business Council for Sustainable Development (WBCSD, 1999) viewed CSR as a continuous commitment by business to behave ethically and contribute to economic development while improving the quality of life of the workforce,their families and society at large. CSR means different things to different stakeholders, and Baker (2007) highlighted that in different countries there will be different priorities and values that will shape how business undertakes its CSR. The WBCSD in its publication Making Good Business Sense also highlighted some evidence of the different perceptions of CSR from a number of different societies across the world.(Othman, 2009)

CSR literature identifies several driving forces behind the growing trend towards CSR initiatives: (Wajdi Dusuki, 2008)

1. There is growing market pressure, wherein customers, employees, or capital markets exert some form of 
Corporate social responsibility:An Islamic Perspective

preference, pressure or signal. Social and ethical issue shave received increasing public attention and affected market performance, in addition to the traditional price and brand preferences. The growth of the ethical investment industry is another indicator of how much emphasis people are now apparently placing on the social and ethical behaviour of companies.

2. There has been an increasing regulatory pressure ranging from reporting requirements to government regulations that introduce compulsory business standards by which companies of all sizes have to abide.

3. Increased power of communications (e.g. internet, electronic media, and others) have driven consumers and pressure groups like social activists, nongovernmental organizations (NGOs) and trade unions to scrutinize the activities of companies more effectively and develop strategies that may influence companies to act in a socially responsible way.

4. There is a competitive advantage that companies 
believe they can reap by being socially responsible. They foresee that by communicating effectively about their social, environmental and economic contributions, they can strengthen their brand, enhance their corporate reputation with customers and suppliers, and attract and retain a committed and skilled workforce. Indeed, extant literature asserts that, the commitment to CSR will in turn lead to better performance in terms of profitability, competitiveness and risk management.

\section{ISLAMIC CORPORATE SOCIAL RESPONSIBILITY}

The prevailing concept of corporate social responsibility refers to the expectations that society has of business not to harm, and also to contribute positively to the well being of others. Corporations have numerous responsibilities to all those who have a stake in it and these responsibilities derive 
Corporate social responsibility:An Islamic Perspective

from ethical principles and moral values. Similar values with features consistent with CSR also exist in Islamic values and moral philosophy. This section will elaborate this by looking at Islam and the basic principles of this religion that also govern commercial life and highlight the presence of a rich vein of values and principles in Islamic jurisprudence (figh) similar to the prevailing notion of CSR.

The concept of social responsibility in Islam is discussed in light of Islamic religious values and beliefs according to Shariah, the sacred law of Islam derived from the holy Qur'an (book of divine revelation), Hadith (sayings and deeds of the holy Prophet Mohammed [PBUH]), Ijma (consensus), Qiyas (reasoning by analogy), and Maslaha (public interest). The purpose of the Islamic system (maqasid al Shariah) is material as well as spiritual. The goal of an Islamic social system is based on falah (human well-being) and hayat tayyibah (good life), both of which stress brotherhood and socio-economic justice, as well as a balance between the material and spiritual requirements of all human being that is necessary to preserve and enrich faith, life intellect, posterity and wealth. The concept of social responsibility and justice in Islam in light of the holy Qur'an 
and Hadith suggests that there seems to be congruence between the ideals of social responsibility and justice and business transactions in Islam that has a resonance with prevailing notions of corporate social responsibility (CSR). This perspective on social justice and responsibility lays the foundation for the study of Islamic understandings and practice of corporate social responsibility. From this viewpoint, within Islam, as it is practiced amongst Muslims, the relationship between commercial activity and civil society is taken as natural and the rules of practice are embedded in the Islamic precepts. (Mohammed, 2013)

\section{The Concepts Of Business Ethics And Corporate Social Responsibility}

There has been over the last three decades a growing emphasis on companies to conduct ethically sound behaviour and practice behaviour governed by ethical code of conduct prescribed by the corporate policy. The birth of industrialization did not bring the need for ethics but the 
Corporate social responsibility:An Islamic Perspective

drastic consequences did, in the form of child labour, dishonest trade, lack of systematic procedures and inequity in various aspects in the businesses. Social awareness from 1960s onwards forced companies to consider ethical behaviour, which refines their actions morally and in turn produces a positive image of the company in the eyes of the existing or potential customers and the society as a whole in which the company operates. But this is where the debate arises. Ethics are good for business, as it has been claimed by many business authors. However, ethical decision making is by the most complex decision making situation that companies face today. What is ethically right to one is wrong to another. This so happens owing to the definition of ethics, according to which it is the discipline that examines one's moral standards or moral standards of the society. Every individual and society has its own set of values, beliefs and morals and the resultant is a conflict among different ethical decisions which pose a dilemma for managers of companies which are fast expanding across the global and taking into consideration a diverse customer base as well as a diverse workforce belonging to different cultures and different moral orientations. Following strong ethically behaviour and 
catering to the rights of individuals and societies which are major stakeholders in the companies, companies follow a socially responsible behaviour which is quality of running a good business. The need for companies to be socially responsible and ethically sound is a complex issue for the companies as they put forward cost complications as well. But nonetheless, the argument that good ethics are good for businesses is well supported and companies who are not following ethically sound behaviour are facing tremendous challenges in sustaining profitable performance of their operations. It has been argued that commitment to socially responsible behaviour and ethically sound practices is an effective long term strategy and it may lead to short term losses but its benefits are spread across the longer run, which companies have to realize to adapt. The concept of sustainable value emerges in the context of long term corporate social responsibility which companies are increasingly benefiting from. ${ }^{7}$

\footnotetext{
7 Find out more from UK Essays here: http://www.ukessays.com/essays/business/the-concepts-of-business-ethics-andcorporate-social-responsibility-business-essay.php\#ixzz3YEly3mx1
} 
Over the past 50 years, business ethicists and management theorists have devoted much effort to thinking through the business-society relationship. These ethicists developed models that could be modified or compromised to suit evolving social interests. In general there are six major ethical models that now dominate ethical thinking leading to the concept of corporate social responsibility. These can be summarized as following: (Mohammed, 2007)

1. Relativism - Ethical decisions are made on the basis of self-interest and needs, excluding any interaction with or input from the outside.

2. Utilitarianism - Ethical decisions are made on the basis of calculating costs and benefits. Utilitarianism is generally considered outcome oriented. Whatever is good for majority is considered ethical.

3. Universalism - Ethical decisions stress on the intention of the decision or action (duty). Everyone under similar circumstances should reach similar decisions.

4. Rights - Ethical decisions stress a single value - liberty, and are based on individual rights (individual entitlement) 
ensuring freedom of choice.

5. Distributive Justice - Ethical decisions revolve around a single value - justice. To be considered ethical, decisions and actions should ensure an equitable distribution of wealth and benefits (fairness and equality).

6. Eternal Law - Ethical decisions are made on the basis of eternal law, which is revealed in scripture.

These ethical models provide a background to the concept of corporate social responsibility. There have been efforts to conceptualise ethical behaviour in terms of business practices of corporations in society. Much of this work has specifically focused on theorizing what responsibility corporations have to society and what the consequences of related actions or inactions are.

In Islamic perspective, CSR encompasses a broader meaning embracing the value of righteousness (taqwa) in all situations, by which everyone in the organization must play his/her roles and responsibilities as servant and vicegerent. A person with righteousness value understands their role in 
Corporate social responsibility:An Islamic Perspective

this worldly life is to manage and develop the world in accordance with the shariah principle and value. The core principles of Islamic CSR are derived from Qur'an and Sunnah, while the major foundations of Islamic CSR principles are unity, vicegerency and trusteeship, justice and equilibrium, and rights and responsibilities .(Arsad, Ahmad, Fisol, Said, \& Haji-Othman, 2015)

1. Unity

Unity of Allah is the first principle in Islam, because Allah is the One and absolutely One who creates the earth and universe. The Qur'an (57:5) states that Allah is the ultimate owner of everything on earth and universe and man is ultimately accountable to Allah (Qur'an, 2:28). It means that, by accepting Unity of Allah, all commercial activities must be in accordance to shariah principle and value.

2. Vicegerency and Trusteeship 
Man is a vicegerent (khalifah) or representative of Allah on earth and trustee of Allah resources. As a khalifah or leader in organization, they have greater responsibility to utilize things that belongs to Allah to utilize all these given facilities by Allah to best of their abilities to create maximum added value to the organization itself and to the whole community as well.

3. Justice and Equilibrium

According to Parvez (2000), human beings are equal and human interactions should be based on trust, equity and justice. In Islam, human beings are khalifah (leaders). In order to fulfill their role as vicegerencies, they should collaborate and support each other, be honest, sincere, keep the promises and truthful in their business dealings. Equilibrium must be practiced by treating people fairly and justly in wage distribution without discrimination. Through justice and equilibrium principle, organization can create harmonious lives in all societies. 
4. Rights and Responsibilities

Every individual is accountable and responsible for his/her own actions. They are free or have a right to steer their own lives because humans have been endowed with intellectual capabilities to choose either to be ethical or unethical. But these rights must always conform to shar'iah rules and ethics as well as preserve and protect the interest of collective well-being.

Islamic CSR and conventional CSR have different values and aspiration because they are operating in different philosophical grounds such as halal (lawful) and haram (unlawful) in its economic system. For the earning livelihood and wealth that have been declared unlawful such as riba (interest), bribery, gambling, short weighing, short measuring and sales of al-gharar (uncertainty, risk, speculation) need to be considered seriously by $S h C C$.

But the dimension and area of CSR as proposed by traditional theoreticians and international bodies may well be applied to Islamic business firms since most of them are 
consistent with the spirit and teaching of Islam or predominately based on the Qu'ran and Sunnah. Table 1 shows the dimensions of CSR which was introduced by Bursa Malaysia and the contemporary CSR issues that are applicable to Islamic business.

\section{Benefits of Corporate Social Responsibility}

The concept of CSR and its practical application does not go without debate. Critics argue as to whether CSR is actually a benefit or a disadvantage to society. Norris (1981) indicates that there is growing controversy between the SR of business and the profit making responsibility of business. Friedman (1970) questions, what it means to say that business has responsibilities? Smith (1990) supports this perspective and proposes five additional arguments against CSR: $\underline{\text { A. Othman }}$ $\underline{\text { \& Mia, 2008) }}$ 
Corporate social responsibility:An Islamic Perspective

(1) Business's function is economic, not social and as such the role of business is solely to make a profit.

(2) CSR will have a price for the firm as it refers to capital outlay in one form or another and therefore results in a competitive disadvantage for the company.

(3) This point questions whether companies have the skills and knowledge to deal with social issues. Friedman (1970) supports this ideology and questions, if businessmen do have a responsibility other than profit seeking, how are they to know what this responsibility is?

(4) This concept highlights that combining social activities with the economic activities of business would give business an excessive concentration of power.This argument supposes that private organisations should not take on the role of public organisations.

(5) The final argument presupposes that social issues are the concern of

government thus companies pay taxes so that these issues may be resolved by government and therefore there is no need for additional CSR on the part of business.

On the other hand there are a significant number of positive arguments associated with CSR. Colmer (2003) and 
Kotler and Lee (2005) highlight the benefits of CSR as: $\underline{\text { A. }}$ Othman \& Mia, 2008)

. Improved financial performance, increased sales and market share.

. Better risk and crisis management.

. Reduced operating costs, decreased operating costs.

- Increased worker commitment, increased ability to attract, motivate and retain

employees.

. Enhanced brand value and reputation, strengthened brand positioning.

. Good relations with government and communities.

. Long-term sustainability for your company and society.

. A licence to operate.

. Long-term return on investments.

. Increased productivity.

. Enhanced corporate image and clout.

. Increased appeal to investors and financial analysts.

Nur Diana Hidayati, (2011), stated that Corporate Social 
Corporate social responsibility:An Islamic Perspective

Responsibility, is one of the action done by the business world. Lesmana,(2007) cited in In Nur Diana Hidayatu, (2011), said that this course of action is taken to encourage companies to run out the day to day activities ethically, to cut off the negative effects on communities and the environment to gain sustainable economic benefits.

Nur Diana Hidayati, (2011), found that the present trend shows that most business entities are unwilling to relate to CSR programs due to the inherent cost. In the short term the benefits of CSR cannot be seen, but in the long run the programs will contribute financially directly and indirectly. Nur Diana Hidayati, (2011), consequently said that company should carry out CSR programs constantly to make them as an investment and an element of company's business strategy where all parts of the business entity are agreeable to put into practice tailored CSR programs.

Nur Diana Hidayati, (2011), affirmed that fianancially, the expenses concerning CSR activities are clearly accounted in to implement the programs incessantly as anticipated by the stakeholders. Elkington,1997 : cited in Siltaoja, 2006 that the triple bottom line is a 'key to sustainable development' Opportunity, innovation and competitive excellence leads to 
competititve advantage (Porter and Kammer, 2006) Lesmana, 2007: cited in Nur Diana Hidayati, 2011, declared that a continuous CSR activity will help set up a flourishing and autonomous society.(Hidayati, 2011)

According to the World Business Council on Sustainable Development (2001), a sustainable development accomplishes the present needs without forfeiting the capacity of the next generations in accomplishing their needs (Porter and Kamer, 2006).

The International Institute for sustainable Development and Deloitte and Touche dentified sustainable development of companies as accepting strategies and programs to accomplish the current company's needs and the needs of stakeholders at the same time guarding, sustaining and enhancing the human and natural resources required in the future(Labuschagne and Brent, 2005; cited in Malovics et al., 2007).8

8 Find out more from UK Essays here: http://www.ukessays.com/dissertations/sociology/corporate-socialresponsibility.php\#ixzz3YEBZSMt4 
The influence of Islam on business practices are well documented in the Holy Qur an and Sunah, which are the main sources of business ethics in Islam. Islamic business values such as justice, socio-economic measure, human wellbeing, honesty etc are considered as the core of CSR in Islam. Islamic financial Institutions (IFIs) are considered as having an ethical identity and they have different social and economic objectives since the foundation of their business is based on religion .(Ali Aribi \& Gopinath Arun, 2012; Haniffa \& Hudaib, 2007; Maali, Casson, \& Napier, 2006)

The general objective of IFIs is to contribute to the development of the economy within the boundary of Islam. Within the range of Shari'a (Islamic law), IFIs are expected to be guided by an Islamic economic worldview, which is based on the principle of social justice and the well-being of society.(Wajdi Dusuki, 2008)

Islamic Financial Institution (IFI) are like any other conventional financial institution, which acts as an intermediary between providers of funds and fund users, the only difference being that the transactions and contracts of 
an IFI must comply with Islamic law.

Growing awareness of and demand for investing in accordance with Islamic ethical principles on a global scale have been catalyst towards making the Islamic banking and financial system as a flourishing industry. This is also a reflection of increasing wealth and capacity of investors, both Muslim and non-Muslim, to seek and invest in new investment products that serves their needs. The Islamic financial institutions (IFIs) earn profits as the other business firms earn profits. Many people say that IFIs should have involved "strategic charity" activities. Business of IFIs including Islamic banks is based on Shari'ah principles which need the IFIs to operate with the commitment of social responsibility.(assan \& Latiff, 2009)

In the context of IFIs, the Association of Accounting and Auditing Organization for Islamic Financial Institutions (AAOIFI) has issued specific standards on CSR known as Governance Standards No. 7: Corporate Social Responsibility, Conduct and Disclosure for IFIs. According to the (AAOIFI), Corporate Social Responsibility (CSR) for 
Corporate social responsibility:An Islamic Perspective

IFIs refers to all activities carried out by an $\mathrm{IFI}^{9}$ to fulfill its religious, economic, legal, ethical and discretionary responsibilities as financial intermediaries for individuals and institutions. Religious responsibility refers to the overarching obligation of IFIs to obey the laws of Islam in all its dealings and operations. Economic responsibility refers to the obligation for Islamic banks to be financially viable, profitable and efficient. Legal responsibility refers to the obligation of IFIs to respect and obey the laws and regulations of the country of operation. Ethical responsibility refers to the obligation of IFIs to respect the mass of societal, religious and customary norms which are not codified in law. Discretionary responsibility refers to the expectation from stakeholders that IFIs will perform a social role in implementing Islamic ideals over and above the religious, economic, legal and ethical responsibilities.( $(\underline{A \text { OIFI, n.d.) }}$

The core foundations of CSR are the same as the

9 The IFIs referred to any institution that plays the role of a financial intermediary that strictly abides by the provisions of the Shari'a. These include, but are not limited to Islamic banks and Islamic Insurance companies. 
foundations for individual social responsibility of each Muslim: to enjoin right and to forbid wrong. The definition of right and wrong in Islam can be defined in various dichotomies which are overlapping. In their legal form, right refers to everything that is permissible or recommended (Halal and Mustahab respectively), while wrong refers to everything that is impermissible or not recommended (Haram and Makruh respectively). From the perspective of Islamic jurisprudence, right refers to what is just while wrong refers to what is unjust.

However, because IFIs are a collective religious obligation (Fard Kifayah), the definition of right and wrong are sometimes of a different nature than those that apply to individuals. This is because IFIs have a special religious and financial position in society.

Religiously, IFIs have a responsibility to comply with the form and substance of Islamic law in all aspects of their operations. This is because they are in an exemplary position. This means that all aspects of its operations should be conducted in a permissible or recommended manner while 
Corporate social responsibility:An Islamic Perspective

no aspect of its operation should be conducted in an impermissible or not recommended manner. If it is conducted in an impermissible or not recommended manner, it is an obligation to disclose to its stakeholders the reasons for that particular conduct.

At the beginning of 2010, a new standard from the Accounting and Auditing Organization for Islamic Financial Institutions (AAOIFI) went into effect to define and outline the responsibilities of Islamic financial institutions with regards to corporate social responsibility (CSR). The rationale for the standard is clearly spelled out in an appendix to the standard: ${ }^{10}$

"A number of IFIs engage in supporting activities that are not within the definition of social responsibility as espoused by Islamic scholars and thinkers. Rather they are perceived to be marketing ploys to enhance the reputation of the IFI,

10 See: Blake Goud, AAOIFI standard lays out CSR obligations, but Islamic banks rarely provide full disclosure , 09 Mar 2015 . at: http://blog.thomsonreuters.com/index.php/aaoifi-standard-lays-csr-obligationsislamic-banks-rarely-provide-full-disclosure/ 
with little direct social or environmental improvement".

AAOIFI In identifying what 'Islamic social responsibility' is, AAOIFI built it up based on concepts of viceregency, divine accountability, enjoining good and forbidding evil and the 'collective religious duty' placed on Islamic financial institutions by virtue of their acting on behalf of their individual customers. It is the final aspect of these principles that is the most unique to the institutions. In addition to an IFI being subject to the same rules of conduct as individuals, they are placed under a higher obligation that they should be 'exemplary' organizations and as such avoid discouraged (makruh) activities even though they are not prohibited under Shariah rules.

In addition to the requirement to avoid discouraged activities, Islamic financial institutions have other requirements under AAOIFI's CSR standard, some of which are being followed by many IFIs, and others which are not as widely adopted. These can be broken up into a couple ideas that form the basis for the CSR requirements, recommnedations and voluntary activities: 
- An IFI must directly assist individuals or societies

- To enhance their living or environmental conditions

- Or to assist them to better comply with religious rules and norms

- And IFIs should not boast of their socially responsibility activities to enhance their own image

- However, because Islam encourages accountability, they should be held accountable by their stakeholders for their CSR

Indeed, the founding fathers of modern day Islamic finance have concurred to the view that IFIs do have a heightened sense of social responsibility, as do any other 'Islamic' institution. However, this does not entail IFIs to become uncompetitive and unprofitable charitable organizations used to only further social development objectives. This entails a change in the mindset of Islamic bankers to incorporate social development objectives into their portfolio of investments profitably. As more 
investment account holders, shareholders and general stakeholders understand fully the objectives that underlie the Islamic economic system, there shall be more demand to know to what extent their local IFI fulfils those social objectives. Therefore, the IFI that extensively involves itself in CSR and demonstrates by disclosure that it is extensively involved in CSR will more easily earn the legitimacy of certain stakeholders (particularly those interested in the IFIs CSR activities), and ultimately earn their loyalty. This represents in itself a value proposition for IFIs who seek to retain clients on the basis of non-price competition. However, this is not to say that IFIs should implement corporate social responsibility because of its long term economic benefits. While viable economic institutions have to be driven by profit incentives, in the case of IFIs, it is not their only priority and certainly not the only reason for them to implement corporate social responsibility. Indeed, any notion that IFIs or any other institution that claims to be Islamic, for that matter, should be socially responsible must derive its justification from Islamic law and principles, as contained within the Qur'an and the Sunnab of the Prophet of Islam, Muhammad (P.B.U.H). Without this ultimate 
Corporate social responsibility:An Islamic Perspective

source of legitimacy, there is no reason for any action.(Farook 2007)

In the contemporary environment, business organizations have to face up to the task of meeting the expectations of a wide variety of their stakeholders. A 'stakeholder' is normally defined as someone that can be considered to have an interest (a stake), indirect or direct, in the company's operations. The UN defines 'stakeholder' as “any group or individual which is affected by the operations of the Company". Such stakeholders could be external like unions, consumers, suppliers, society, government, creditors, and shareholders or internal like employees, managers, and directors. Each category of stakeholders has a distinct interest and expectations from an organization. Owners (shareholders) expect an organization to maximize profits, the government expect organizations to meet their tax and legal obligations, management staffs also expected to meet performance and growth targets, non-managerial staff expects high rate of pay and job security. Trade unions expect to enjoy better working conditions and minimum 
wage requirements, customers expect organizations to offer value, quality, customer care and ethical products. Consumers are demanding more out of organizations than simply a quality product at a low price. Consumers expect organizations to demonstrate congruence with some social values as part of their contribution to the community. Creditors on their part expect organizations to have good credit scores, secure new contracts and have more liquidity and finally the local community from which organizations taps its resources expect the organizations to offer them jobs and take environmental issues seriously. Corporate organizations have to meet the expectations of each group of stakeholders without jeopardizing that of another stakeholder group. To meet these expectations with some reasonable degree of effectiveness, organizations are obliged to adopt a broader agenda which takes these diverse expectations into account. Nowadays, corporate organizations address these broad agenda by becoming socially responsible. Corporate Social Responsibility is thus increasingly adopted by organizations operating at national and international levels to address these varied stakeholder's expectations. (Shamim \& Karim, 2010) 
Hussein Elasrag 



\section{THE BASIS FOR ISLAMIC SOCIAL RESPONSIBILITY}

While Islamic law is represented in the Shari'a which is composed of a body of rules driven from the Qur'an, the Sunna, the Ijma', the Qiyas and other secondary sources, as mentioned earlier, Islamic ethics may be argued to refer to the general Islamic principles and moralities. In terms of business, Sharia addresses business ethics in different ways. On one hand, the rules of the Shari'a organize the different aspects of Muslimse behavior including their business relationship, as mentioned earlier. Examples may include the prohibition of interest on loans, the necessity of fair determination of prices, and the prohibition of trade in certain products that may 
have negative effect on the body such as liquors, drugs.(Radwa, 2011)

Indeed, values and principles that have been central to Islam since the time of the holy Prophet Mohammed (Peace and blessings be upon him - PBUH) 14 centuries ago may serve as a foundation for notions of corporate social responsibility similar to the West. For example, the holy Qur'an has enjoined that the economic success of business will flourish if it is underpinned by morality and businesses are reminded to "... give full measure when you measure, and weigh with a balance that is true..." (Qur'an, Sura Al Israa-17: 35). Thus, the convergence between Islam's focus on morality and the economic orientation of business is very apparent.

Shari'ab(or Islamic law) is meant to regulate all aspects of a Muslim's way of life. It is broadly divided into two sets of rules: one relates to the obligatory worship of God (ibadab) and the other relates to daily life outside the context of obligatory worship (muamalat), including commercial and financial dealings. Shari'ah is not a 
codified body of law. It consists of general rules and principles derived from the Qur'an (the Muslim holy book), the practices (sunnab) and sayings (abadith) of the Prophet Mohammed (as discussed in further detail below). These general principles are capable of interpretation and development to address new issues or circumstances that arise from time to time. Indeed, the Shari'ah has been supplemented by extensive Islamic jurisprudence (fiqh) developed over centuries by different schools of thought (the madha' hib). The key point to note is that, while all the schools of thought agree on the fundamental Shari'ah principles enshrined in the Qur'an, sunnah and hadith, they sometimes hold differing views on their interpretation and application.

\section{-Sources of Shari'ah law}

Shari'abl aw is derived from a number of primary and secondary sources.(Allen\&OveryLLP, 2009)

\section{-Qur'an}

The Qur'an is a primary source of law and is believed 
by Muslims to contain the word of God as revealed to the Prophet Mohammed. Evidence found in other sources of Shari'ah law is subject to the Qur'an.

\section{-Sunnah}

Sunnah literally means "well known path". The Sunnah is a primary source of law and comprises traditional accounts of what the Prophet Mohammed said or did during his life

Which have legal content. Sunnah also comprises the sayings of others tacitly approved by the Prophet's silence.

\section{-Hadith}

A further primary source of law is the narrative record of sayings and actions of the Prophet Mohammed known as hadith (plural abadith). The extent to which sunnab is derived or differentiated from ahadith depends on the context and school of thought being considered.

\section{-Qiyas}

Qiyas represents the process of reasoning whereby the principles found in the Qur'an and sunnah are extended to 
Corporate social responsibility:An Islamic Perspective

new cases by analogy.

-Ijma

Ijma represents the consensus of the Islamic community (whether at a local or global academic level) on a particular issue.

\section{-Ijtihad}

Ijtihad is the interpretation and the opinion of Islamic jurists on a particular issue. Qiyas,ijma and ijtibad are all secondary sources of Shari'ah law.

\section{-Issues relating to interpretation and application of Shari'ah law}

Since Shari'ah law is not a single codified body of law and is open to interpretation, the opinions of Shariah scholars may differ on the same question of Shari'ah law depending on the school of thought to which particular scholars belong. In addition, scholars' views on questions of Shari'ah law may change over time. This can lead to uncertainty and inconsistency of interpretation and application of Shariab law across the Islamic world.(Allen\&OveryLLP, 2009; Ayub, 2009) 


\section{-Key Shari'ah principles and prohibitions relevant to finance}

There are a number of key Shari'ah principles and prohibitions relevant to finance and commercial transactions which distinguish Islamic finance from the conventional forms. For completeness, it should be mentioned that there are two main branches within Islam: sunnism and shiaism. The majority of Muslims are sunni and the following is limited to the discussion of the general Shariah principles relating to Islamic finance within sunni jurisprudence. The key Shari'ah principles which underpin Islamic finance, and have led to the creation of a separate finance industry, are as follows:(Allen\&OveryLLP, 2009)

-Prohibition on usury and interest (riba)

Prohibition of interest. Prohibition of riba, a term literally meaning "an excess" and interpreted as "any unjustifiable increase of capital whether in loans or sales" is the central tenet of the system. More precisely, any positive, fixed, predetermined rate tied to the maturity and the amount of principal (i.e., guaranteed regardless 
of the performance of the investment) is considered riba and is prohibited. The general consensus among Islamic scholars is that riba covers not only Usury but also the charging of "interest" as widely practiced. This prohibition is based on arguments of social justice, equality, and property rights. Islam encourages the earning of profits but forbids the charging of interest because profits, determined ex post, symbolize successful entrepreneurship and creation of additional wealth whereas interest, determined ex ante, is a cost that is accrued irrespective of the outcome of business operations and may not create wealth if there are business losses. Social justice demands that borrowers and lenders share rewards as well as losses in an equitable fashion and that the process of wealth accumulation and distribution in the economy be fair and representative of true productivity.

Under the Shari'ah, it is not permissible to charge, pay or receive interest. The Shari'ah does not recognize the time value of money and it is therefore not permissible to make money by lending it. Money must be used to 
create real economic value and it is only permissible to earn a return from investing money in permissible commercial activities which involve the financier or investor taking some commercial risk. This prohibition is the main driving force behind the development of the modern Islamic finance industry. Riba can take one of two forms: riba al- naseeyah and riba al-fadl.(Dewar \&

\section{Hussain, 2011, p. 274)}

1-Riba al-naseeyah is the amount of excess received by a lender in addition to the capital amount lent. This type of riba is comparable to the traditional concept of interest in conventional lending

activities.

2- The second type, riba al-fadl, is excess compensation without any form of consideration in return.

In modern finance, riba al-fadl could be applicable to several exchange of commodities contracts.

The idea is that when compensation is paid, it should be justified or be set against a specific activity and the return should also be associated with a specific risk. Therefore when parties exchange commodities of similar value and one party pays excessive compensation to the 
Corporate social responsibility:An Islamic Perspective

other party, this is

Considered riba.

\section{- Prohibition on realising a gain from speculation (mayseer)}

It is not permissible to earn a profit from speculation. Gambling is therefore not permitted under Shari'ah. Any contracts or arrangements which involve speculation are also not permitted. That said, it is accepted under the Shari'ah that there is an element of speculation in most commercial arrangements and, unlike the absolute prohibition of interest, it is a question of the degree of speculation involved and whether the intention behind the transaction is to realise a gain from some productive effort or purely speculation.

The distinction between prohibited speculation and legitimate commercial speculation is not always clear in practice and there are examples where it can be difficult to distinguish between the two. For example, it is generally accepted that it is permissible to make an equity investment in a company Engaging in a business activity 
that is permissible under the Shariah with a view to realising future dividends and capital gains on the investment. There is of course a degree of commercial speculation involved about the future prospects of the company when an investor makes an equity investment, but whether such speculation is permissible or not would depend on the intention of the investor, i.e. was the intention to make a quick profit by speculating in the likely movement of the share price over a very short period of time (as is arguably the case with day trading), or was the decision made on the basis of careful evaluation of the company's past results and future prospects?At the other end of the spectrum, equity derivatives such as index-linked derivatives are generally viewed as unacceptable under Shariah because they involve speculation on the movement of an equity index.(Allen\&OveryLLP, 2009)

\section{-No uncertainty (gharar) in commercial transactions}

Certainty of terms in any transaction is a key requirement under the Shariah. Again, as with 
speculation, a degree of commercial uncertainty is acceptable but there must not be any uncertainty about the key terms of the transaction. For example, in a transaction for the sale of assets, the sale contract should set out a clear description of the assets being sold, the sale price and the time for delivering the assets to the purchaser. Similarly, a leasing contract needs to set out clearly the assets which are being leased, the duration of the lease and the rent payable under the lease. One of the reasons that conventional insurance contracts are not considered permissible under the Shari'ab is that there is no certainty as to when a claim will be paid, given that there is no way of knowing if and when the insured event will occur. In the context of modern day Islamic finance, key examples of gharar are:(Allen\&OveryLLP, 2009; Uusmani, 2002)

(a) Advising a customer to buy shares of a particular company that is the subject of a takeover bid, on the grounds that its share price can be expected to rise;

(b) Buying a house, the price of which is to be specified in the future; 
(c) When the subject matter or specifications to a contract are unknown; and

(d) Deferred payment under a contract where the deferment is for an unknown period.

- All activity must be for permitted purposes (halal)

Muslims must not engage in (or derive any benefit from) activities which are prohibited under the Shari'ah. It is therefore not permissible for Muslims to invest in businesses which engage in prohibited activities such as casinos, a breweries or a factories making pork products. It is also not permissible for Islamic banks to provide any financing to such businesses. However, a very strict interpretation of these rules would mean that Muslims would only be able to invest in a very limited number of businesses internationally. For example, it would not be permissible for Muslims to invest in a hotel that serve alcohol, a food company which also manufactures pork products as part of its product range or any business that lends or borrows money at interest. 
In light of the practical considerations of international commerce and in order to enable Muslim investors to participate in it, a number of prominent Shari'ab scholars have advanced the view that it is permissible for Muslims to invest in businesses or companies which are not entirely Shari'ah compliant so long as certain conditions are met. These conditions include (among other things):

(a) The principal business activity must be permissible under Shari'ah;

(b) Any income derived from prohibited activities should only form a small percentage of the overall income of the company or business (this percentage ranges from 5 to 20 per cent. Of overall income depending upon the nature of the prohibited activity and the Shariah scholars involved);

(c) The aggregate amount of interest-bearing debt incurred by a company or business must not exceed a certain percentage of

its assets or market capitalisation (there are disagreements between Shariah scholars as to what percentage is acceptable and it ranges from 25 to 35 per 
cent. of total assets or market capitalisation depending upon the scholars involved); and

(d) The accounts receivable of the company on the business must not exceed a certain percentage of its assets or market capitalisation (usually set between 25 and 33 per cent.).

- Making Money from Money is not Permissible

One of the wrong presumptions on which all theories of interest are based is that money is a commodity. It is, therefore, argued that just as a merchant can sell his commodity for a higher price than his cost, he can also sell his money for a higher price than its face value, or just as he can lease his property and can charge a rent against it, he can also lend his money and can claim interest thereupon. Islamic principles, however, do not subscribe to this presumption. Money and commodity have different characteristics and, therefore, they are treated differently.

The basic points of difference between money and commodity:- 
(a) Money has no intrinsic utility. It cannot be utilized in direct fulfillment of human needs. It can only be used for acquiring some goods or services. A commodity, on the other hand, has intrinsic utility and can be utilized directly without exchanging it for some other thing.

(b) Commodities can be of different qualities while money has no quality except that it is a measure of value or a medium of exchange. Therefore, all the units of money of the same denomination, are hundred per cent equal to each other. An old and dirty note of SR.100 has the same value as a brand new note of SR.100.

(c) In commodities, the transactions of sale and purchase are effected on an identified particular commodity. If A has purchased a particular car by pinpointing it, and seller has agreed, he deserves to receive the same car. The seller cannot compel him to take the delivery of another car, though of the same type or quality. Money, on the contrary, cannot be pinpointed in a transaction of exchange. If $\mathrm{A}$ has purchased a commodity from $\mathrm{B}$ by showing him a particular note of 100 SR.100 he can still pay him another note of the same denomination. 
Based on these basic differences, Islamic Shari'ah has treated money differently from commodities, especially on two scores: Firstly, money (of the same denomination) is not held to be the subject matter of trade, like other commodities. Its use has been restricted to its basic purpose i.e. to act as a medium of exchange and a measure of value. Secondly, if for exceptional reasons, money has to be exchanged for money or it is borrowed, the payment on both sides must be equal, so that it is not used for the purpose it is not meant for i.e. trade in money itself. In short, money is treated as "potential" capital. It becomes actual capital only when it joins hands with other resources to undertake a productive activity. Islam recognizes the time value of money, but only when it acts as capital, not when it is "potential" capital.

The concept of social responsibility and justice has been the foundation of an Islamic society since its advent in the seventh century. The holy Prophet Mohammed 
Corporate social responsibility:An Islamic Perspective

(PBUH) exemplified the principles of social responsibility and justice embedded in the holy Qur'an through his practices (Sunnah) to establish a social system that was just and harmonious. These principles that permeate every aspect of a Muslim's life, also governs Islamic business and commercial practices.

However, a large part of Islamic literature is either theologically oriented or superficial and inadequate in its assessment of Islamic business principles and remains to date, fragmented and spread over a variety of sources. These existing literatures on Islamic economics fail to provide a systematic model or framework of business practice similar to the notion of CSR despite the existence of a rich vein of the concept of social responsibility and justice in Islam. (Mohammed, 2007, 2013)

ICSR derives itself from core principles in the holy Qur'an. The three major foundational principles for ICSR are the vicegerency of mankind on earth, divine accountability and the duty on mankind to enjoin good 
and forbid evil.(Farook 2007)

\section{A. Vicegerency}

The principle of vicegerency denotes that mankind is the representative of Allah on earth and as such Allah has entrusted mankind with stewardship of Allah's possession.

\section{B. Divine Accountability}

The principle of divine accountability flows from the vicegerency principle and denotes that individuals will be accountable to Allah for all of their actions on the Day of Judgment. This principle is expounded in several verses of the holy Qur'an. This divine accountability is the basis for all actions of a Muslim, and in turn the representative organizations of Muslims.

\section{Enjoining Good and Forbidding Evil}

The principle of enjoining good and forbidding evil encapsulates the responsibilities that Allah places on Muslims as trustees and vicegerents.

We can surmise that most of the informal rituals or ibadah maybe categorised as being components of CSR. Therefore undertaking CSR initiatives is akin to 
performing ibadah. CSR in Islam is one of the essential

human tasks which is a mandate from Allah. On one hand CSR is an act of obedience to Allah, while on the other hand it is a manifestation of human responsibility as the vicegerent of Allah on earth. Therefore, those who are bestowed with advantages and elevated positions by Allah are obliged to help others. The concept of vicegerency denotes that mankind is the representative of Allah on earth and as such Allah has entrusted mankind with the stewardship of all of His possessions. notes that organizations have been endowed with the power by Allah to conduct business in accordance with His laws. He notes that there are situationswhere a corporation endeavours to generate profits for its shareholders, while simultaneously attempting to maintain and further enhance the economic resources of society. In the process, the company's management has to be equally aware of issues such as good environmental

practices, safety, charitable contributions, social benefits and avoiding dangerous activities. All these are done to seek Allah's pleasure. 
The paradigm of taqwa (piety) means a person is imbued with a strong understanding that their role in this world is to manage and develop the world in accordance with the Shariah. This means harmonizing and integrating material well-being with moral-spiritual values, which in turn determines their fate in this world and in the Hereafter. It provides a number of values for shaping social life and clarifies the status of human beings and their position in relation to the rest of creation.

Furthermore, it defines the nature of human beings 'relationship with Allah, with each other and with the natural environment. Mankind therefore shall be divinely accountable to Allah for all their actions on the Day of Judgment.(Zain et al., 2014)

Notions of corporate social responsibility (CSR) have been suggested to be consistent with an Islamic view of society. Indeed, values and principles that have been central to Islam since the time of the holy Prophet 
Mohammed (Peace and Blessings be upon him) may serve as a foundation for notions of corporate social responsibility (CSR) similar to those in the West. Much contemporary discussion of CSR, however, has not recognized this. These discussions have largely been based on a Western orientation informed by Western religious values. Moreover, CSR has evolved literally in response to particular issues or problems that are specific to businesses in a Western context. This led to a lack of a comprehensive global context within which a wider perspective of CSR should be positioned. On the other hand, the notion of social responsibility and justice has been an integral part of Islamic society for nearly 14 centuries. While Islamic philosophy is rich in precepts pertinent to CSR based on the Shariah (the Islamic legal and social system) derived from the Holy Qur'an and Hadith, these precepts have not yet been formally synthesized to present a systematic model with an explicit notion of CSR in Islam. ${ }^{11}$

11 http://www.islamic-banking.com/csr.aspx 


\section{Challenges for Islamic Corporate Social Responsibility}

Some of the key challenges going forward included. $:^{12}$

1. Avoiding Politicization: what types of activities would be socially acceptable from political standpoints, something that would directly impact both community as well as government perception. What is politically acceptable to do for social benefit with private funds? How can engagement programs in countries in which civil society is more restricted be conducted in a matter that will not lead to misunderstandings, backlash, or other problems for the company?

2. Competition: A significant barrier to the adoption of CSR frameworks in Muslim-majority nations (as well as other countries) is the fact that responsible companies will be competing with

12The Hollings Center for International Dialogue, Dialogue Snapshot Corporate Social Responsibility in Islam November 2014 
irresponsible ones. As one participant noted, "Responsible behavior should look like a competitive advantage for companies, but the reality is that being responsible results in losing market share to an irresponsible competitor." How can responsible companies, governments and the local community stop the so-called "race to the bottom?"

3. Coordination: Currently, coordination between CSR practitioners and government, between CSR and educators, between national and local strategies, among stakeholders, and among companies is not good.

4. Responsibility: Who owns the responsibility? The responsibility to the community, the company,the economy? As more and more companies take on CSR activity and public-private partnerships,some participants questioned whether traditional roles of responsibility for social welfare are being 
abdicated and shifted, not just from the government to the private sector, but from the collective to the individual. Is this a good thing or a bad thing? Is this the formation of a new normal? Should it be?

5. Sustainability: Participants considered whether CSR activities could be effectively scaled to create lasting impact and social change. If a particular CSR project is nothing more than a "drop in a bucket," can enough drops eventually fill the bucket? The answer to this question is dependent on the number of small and medium sized businesses that participate in CSR activities. How to get that segment of the economy to participate remains a significant challenge. 
All of these challenges provide a unique opportunity, not only for proponents of CSR,but also for companies and communities that work to support the concept. As these challenges are addressed, CSR will become an important component to the stability and sustainability of corporations. 
Appendices 


\section{LOSSARY}

\begin{tabular}{|c|c|}
\hline Bay' & Sale or contract of sale. \\
\hline Bay`al-'Inah & $\begin{array}{l}\text { A contract involving the sale and buy-back } \\
\text { transaction of assets by a seller. A seller } \\
\text { sells an asset to a buyer on a cash basis } \\
\text { and later buys it back on a deferred } \\
\text { payment basis where the price is higher } \\
\text { than the cash price. It can also be applied } \\
\text { when a seller sells an asset to a buyer on a } \\
\text { deferred basis and later buys it back on a } \\
\text { cash basis, at a price which is lower than } \\
\text { the deferred }\end{array}$ \\
\hline $\begin{array}{l}\text { Commodity } \\
\text { Murābahah }\end{array}$ & $\begin{array}{l}\text { A Muräbahah-based purchase and sale } \\
\text { transaction of Shariah- compliant } \\
\text { commodities, whereby the buyer purchases } \\
\text { the commodities on a deferred payment } \\
\text { basis and subsequently sells them } \\
\text { to a third party on a cash payment basis. }\end{array}$ \\
\hline Darūrah & $\begin{array}{l}\text { Darürah is an exigency in the event that if } \\
\text { the necessary act is not done, then it shall } \\
\text { lead to the destruction of five } \\
\text { fundamental needs, namely religion, life, } \\
\text { intelligence, progeny and property. The } \\
\text { principle of Darürab is only applicable in } \\
\text { exceptional circumstances where the } \\
\text { avoidance of the specific necessary act } \\
\text { shall ruin the said fundamentals. }\end{array}$ \\
\hline
\end{tabular}




\begin{tabular}{|c|c|}
\hline $\begin{array}{l}\text { Fatawa } \\
\text { (singular } \\
\text { Fatwa) }\end{array}$ & $\begin{array}{l}\text { A juristic opinion or pronouncement of } \\
\text { facts given by the Shari ah board, a } \\
\text { Mufti, or a Faqih on any matter pertinent } \\
\text { to Shari ah issues, based on the } \\
\text { appropriate methodology. }\end{array}$ \\
\hline Gharar & $\begin{array}{l}\text { Deceptive uncertainty where details } \\
\text { concerning the sale contract are } \\
\text { unknown or uncertain. }\end{array}$ \\
\hline $\begin{array}{l}I \text { àdat } A l \\
\text { Ijārah }\end{array}$ & $\begin{array}{l}\text { Repurchase } \\
\text { An Ijärah contract is an agreement made by } \\
\text { an institution offering } \\
\text { Islamic financial services to lease to a } \\
\text { customer an asset specified by the } \\
\text { customer for an agreed period against } \\
\text { specified instalments of lease rental. An } \\
\text { Ijärah contract commences with a } \\
\text { promise to lease that is binding on the } \\
\text { part of the potential lessee prior to } \\
\text { entering the Ijarah contract. }\end{array}$ \\
\hline Istisnā' & $\begin{array}{l}\text { An Istisna contract is an agreement to } \\
\text { sell to a customer a non- existent asset, } \\
\text { which is to be manufactured or built } \\
\text { according to the buyer"s specifications } \\
\text { and is to be delivered on a specified } \\
\text { future date at a pre-determined selling } \\
\text { price. }\end{array}$ \\
\hline Kafälah & Guarantee \\
\hline Kafălah bi al- & Charging fee for guarantee \\
\hline Maslahah & Public interest \\
\hline Maysir & Gambling \\
\hline Mu addal & Floating rate \\
\hline
\end{tabular}


Corporate social responsibility:An Islamic Perspective

\begin{tabular}{|l|l|} 
Mu àddal & Fixed rate \\
Mubādalah & Swap \\
Mubādalah al- & Profit rate swaps \\
Arba àh & \\
& \\
\hline
\end{tabular}




\begin{tabular}{|c|c|}
\hline Muḍārabah & $\begin{array}{l}\text { A Mudarabah contract is an agreement } \\
\text { between the capital provider and a skilled } \\
\text { entrepreneur whereby the capital provider } \\
\text { will contribute capital to an enterprise or } \\
\text { activity, which is to be managed by the } \\
\text { entrepreneur as the Mudarib. Profits } \\
\text { generated by that enterprise or activity are } \\
\text { shared in accordance with the terms of the } \\
\text { Mudiarabah agreement, whilst losses are to } \\
\text { borne solely by the capital provider unless } \\
\text { the losses are due to the Mudirib's } \\
\text { misconduct, negligence or breach of } \\
\text { contracted terms. }\end{array}$ \\
\hline Mudāāib & Labour provider \\
\hline Murābahah & $\begin{array}{l}\text { A Muräbahah contract is an agreement } \\
\text { whereby the institution offering Islamic } \\
\text { financial services sells to a customer a } \\
\text { specified kind of asset that is already in } \\
\text { their possession at cost plus an agreed } \\
\text { profit margin (selling price). }\end{array}$ \\
\hline
\end{tabular}




\begin{tabular}{|c|c|}
\hline Mushārakah & $\begin{array}{l}\text { A Mushärakah contract is an agreement } \\
\text { between the institution offering Islamic } \\
\text { financial services and a customer to } \\
\text { contribute capital to an enterprise, } \\
\text { whether existing or new, or to own a real } \\
\text { estate or moveable asset, either on a } \\
\text { temporary or permanent basis. Profits } \\
\text { generated by that enterprise or real } \\
\text { estate/asset are shared in accordance with } \\
\text { the terms of the Mushärakah agreement, } \\
\text { whilst losses are shared in proportion to } \\
\text { each partner" s share of capital. }\end{array}$ \\
\hline $\begin{array}{l}\text { Muslim } \\
\text { Qard / Qard } \\
\text { al-Hasan }\end{array}$ & $\begin{array}{l}\text { A believer in or adherent of Islam. } \\
\text { A non-interest bearing loan intended to } \\
\text { allow the borrower to use the } \\
\text { loaned funds for a period with the } \\
\text { understanding that the same amount of } \\
\text { the loaned funds would be repaid at the } \\
\text { end of the period. }\end{array}$ \\
\hline Rahn & $\begin{array}{l}\text { A contract to pledge a specified asset as } \\
\text { security against a debt whereby the } \\
\text { creditor (Murtabin) is entitled to hold } \\
\text { custody of the asset. In the event of } \\
\text { default by the debtor (Räbin), the } \\
\text { creditor may sell the asset. }\end{array}$ \\
\hline $\begin{array}{l}\text { ReTakāful } \\
\text { Riba } \\
\text { Sadaqah }\end{array}$ & $\begin{array}{l}\text { Islamic re-insurance } \\
\text { Usury } \\
\text { Donation }\end{array}$ \\
\hline
\end{tabular}




\begin{tabular}{|l|l|} 
Salam & $\begin{array}{l}\text { A Salam contract is an agreement to } \\
\text { purchase, at a pre-determined } \\
\text { price, a specified kind of commodity not } \\
\text { available with the seller, which is to be } \\
\text { delivered on a specified future date in a } \\
\text { specified quantity and quality. The } \\
\text { institution offering Islamic financial } \\
\text { services, as the buyer, makes full payment } \\
\text { of the purchase price upon execution of a } \\
\text { Salam contract. The commodity may or } \\
\text { may not be traded over the counter or on } \\
\text { an exchange. }\end{array}$ \\
\hline Shari $\mathbf{a} h$ & $\begin{array}{l}\text { Divine Islamic law that encompasses } \\
\text { all aspects of human life as revealed } \\
\text { in the Qur'an and the Sunnah. }\end{array}$ \\
\hline
\end{tabular}




\begin{tabular}{|c|c|}
\hline $\begin{array}{l}\text { Sukūk } \\
\text { (singular Sakk) }\end{array}$ & $\begin{array}{l}\text { Sukük (certificates) each of which } \\
\text { represents the holder's proportionate } \\
\text { ownership in an undivided part of an } \\
\text { underlying asset where the holder } \\
\text { assumes all rights and obligations to } \\
\text { such an asset. }\end{array}$ \\
\hline Tabarru' & $\begin{array}{l}\text { Grant of property by a person with } \\
\text { complete legal capacity without any } \\
\text { compensation. In the context of Takäful } \\
\text { operations, Tabarru' is the amount of } \\
\text { contribution to be relinquished by the } \\
\text { Takäful participant as a donation for } \\
\text { fulfilling the obligation of mutual help } \\
\text { and to be used to pay claims submitted } \\
\text { by eligible claimants. }\end{array}$ \\
\hline Tahawwut & Hedging \\
\hline Takāful & $\begin{array}{l}\text { Takäful is derived from an Arabic word } \\
\text { which means solidarity, whereby a group of } \\
\text { participants agree among themselves to } \\
\text { support one another jointly against a } \\
\text { specified loss. In a Takafful arrangement, } \\
\text { the participants contribute a sum of money } \\
\text { as Tabarru' (donation) into a common } \\
\text { fund, which will be used for the mutual } \\
\text { assistance of the members against specified } \\
\text { loss or damage. }\end{array}$ \\
\hline
\end{tabular}




\begin{tabular}{|c|c|}
\hline Tawarruq & $\begin{array}{l}\text { Purchasing an asset with deferred price, } \\
\text { either on the basis of Musawamah (sale } \\
\text { contract without the disclosure of the } \\
\text { asset cost price and profit margin to the } \\
\text { buyer) or Muräbahah, then selling it to a } \\
\text { third party to obtain cash. }\end{array}$ \\
\hline Wa'd & $\begin{array}{l}\text { A promise to perform certain action(s) in the } \\
\text { future. }\end{array}$ \\
\hline Wakālah & $\begin{array}{l}\text { An agency contract where the customer } \\
\text { (principal) appoints the institution } \\
\text { offering Islamic financial services as an } \\
\text { agent (Wakil) to carry out business on } \\
\text { their behalf. }\end{array}$ \\
\hline $\begin{array}{l}\text { Waqf(plural } \\
A w q \bar{a} \bar{f})\end{array}$ & $\begin{array}{l}\text { A property that produces income and } \\
\text { that may have been deeded to benefit a } \\
\text { community. }\end{array}$ \\
\hline Zakat & Alms giving \\
\hline
\end{tabular}


Accounting and Auditing Organization For Islamic Financial Institutions Governance Standards

$\begin{array}{lllll}\text { G } & \text { S } & 7 & \text { Corporate } & \text { Social }\end{array}$ Responsibility Conduct and Disclosure for Islamic Financial Institutions 
In the name of Allah, the Beneficent, the Merciful

\section{Introduction}

The purpose of this Governance Standard for Islamic Financial Institutions (GSIFI) is to establish standards on the definition of Corporate Social Responsibility (CSR) for

Islamic Financial Institutions, provide both mandatory and recommended standards to implement CSR in all aspects of the Islamic Financial Institution's (IFI) ${ }^{1}$ activities and provide guidance on disclosure of CSR information to the IFI's stakeholders (para 1).

\section{Scope of this standard}

The principles of this standard are applicable to all IFIs, regardless of their legal form, country of incorporation or size. However, the specific rules and provisions of this standard for activities, compliance and disclosure are classified into mandatory and recommended sections. The mandatory sections are applicable to all IFIs regardless of their legal form, country of incorporation or size. The recommended sections are only applicable to IFIs which have the capacity, financial or otherwise, to carry out or comply with such activities (para 2).

Should the requirements of this standard contradict the IFI's charter or the laws and regulations of the country in which it operates, a disclosure should be made to that effect. Islamic Insurance companies may disregard provisions that are not applicable to their operations (para 3).

\section{Definition of Corporate Social Responsibility for Islamic Financial Institutions}

Corporate Social Responsibility (CSR) for IFIs refers to all activities carried out by an IFI to fulfill its religious, economic, legal, ethical and discretionary responsibilities as financial intermediaries for individuals and institutions (para 4).

Religious responsibility refers to the overarching obligation of IFIs to obey the laws of Islam in all its dealings and operations. Economic responsibility refers to the obligation for Islamic banks to be financially viable, profitable and efficient. Legal responsibility 
refers to the obligation of IFIs to respect and obey the laws and regulations of the country of operation. Ethical responsibility refers to the obligation of IFIs to respect the mass of societal, religious and customary norms which are not codified in law. Discretionary responsibility refers to the expectation from stakeholders that IFIs will perform a social role in implementing Islamic ideals over and above the religious, economic, legal and ethical responsibilities (para 5).

This standard does not focus on economic or legal responsibilities of IFIs as it is assumed that the management/accounting structure and other accounting and governance standards are designed to fulfill economic responsibilities, while legal responsibilities are codified and enforced by the state and its functions (para 6).

\footnotetext{
${ }^{1}$ The IFIs referred to in this standard are defined as any institution that plays the role of a financial intermediary that strictly abides by the provisions of the Shari'a. These include, but are not limited to Islamic banks and Islamic Insurance companies.
} 


\section{Objectives of this standard}

The primary objective of this GSIFI is to prescribe uniform standards on CSR activities and compliance for IFIs. It is not the intended objective of the standard to prescribe new principles and rules of conduct for IFIs, but to codify existing principles and rules in a comprehensive structured format (para 7).

The second objective of this standard is to ensure that the CSR activities and compliance of IFIs are communicated in a uniform, truthful, transparent and comprehensible manner to relevant stakeholders to whom the IFI owes a duty of accountability (para 8).

The objectives of this standard, as stipulated above and the standard itself are intended to encourage IFIs to take a proactive role in applying CSR to all aspects of their operations (para 9).

\section{Responsibilities under this standard}

\section{5/1 Structure of Corporate Social Responsibility}

The responsibilities under this standard are divided between mandatory and recommended conduct. Within mandatory conduct, there are specific responsibilities which an IFI must carry out, while there is guidance on the discretionary methods by which these specific responsibilities may be carried out (para 10).

\section{5/2 Mandatory conduct}

\section{5/2/1 Policy for screening clients}

IFIs shall implement a CSR policy for screening prospective clients. This policy must include

a) Screening criteria

b) The approval of the Shari'a Supervisory Board of the screening criteria (para 11)

The policy stipulating the screening criteria may include provisions:

I. for review of the compliance of prospective client's investments with Islamic law, among other 
aspects, if any, based on the discretion of the IFI,

II. requiring that effective screening processes are in place to prevent third parties from using the IFI to engage in criminal activities such as money laundering

III. for review of the prospective client's compliance with principles and rules of CSR as contained within this standard, particularly mandatory core conduct as stipulated in sections $5 / 2$ (extended to the prospective clients).

IV. for review of the impact of the prospective client's investment on the economy, society and the environment.

V. stating that any future abrogation of the terms of financing, as stipulated under this policy, will result in violation of contractual terms (with the remedy to be decided by the IFI) (para 12).

If these policy terms form part of the contractual agreement with clients, a policy disclosure must be made to prospective clients stipulating these policy terms prior to contractual agreement (para 13). 
$5 / 2 / 2$

Policy for responsible dealing with clients

IFIs shall implement a CSR policy for responsible dealing with clients, including provisions relating to avoidance of onerous terms on clients, marketing ethics, implementing responsible financing practices in all types of transactions with clients and dealing with late repayments and insolvent clients. This policy shall stipulate

a) that all contract forms have to be screened by the Shari'a supervisory board or its agent to avoid the imposition of onerous terms and conditions to clients who are in a weaker bargaining position relative to the IFI,

b) provisions to ensure that all marketing campaigns and documents are ethically balanced promoting business without an exclusive focus on profits that may induce inappropriate behaviour/consumption and unsuitable products inconsistent with Islamic, social and cultural norms,

c) the obligations and rights of each party to transactions undertaken with the IFI,

d) the due process and responsible terms and conditions under which financing is extended to clients, taking into consideration the client's ability to repay and the effect on the client's financial and overall wellbeing, through assessment of the client's present 
disposable income capacity,

e) the remedies available, in the event that one or both parties violate their contractual terms,

f) the opinion of the Sharia Supervisory Board regarding late payment charges,

g) late payment charges to be charged to clients, if any,

h) how the IFI allocates the late payment charges in its accounts (allocation to revenue or charity),

i) the conditions under which IFIs will defer collection of debt from insolvent clients.

A policy disclosure shall be made to clients prior to execution of any contract. This policy disclosure shall form part of the contractual terms and conditions (para 14).

\section{$5 / 2 / 3$}

prohibited by Shari'a

Policy for earnings and expenditure

IFIs shall implement a CSR policy for earnings and expenditure prohibited by Shari'a. (impermissible or haram transactions). This policy must include a due process procedure wherein the following must be documented for impermissible transactions:
a)
Specific description of each material transaction and aggregate description of accumulated immaterial transactions
b) revenue, expense, liability or asset amount of each material transaction and aggregate revenue, expense, liability or asset amount of accumulated immaterial transactions,
c) reasons for undertaking such transactions,
d) the Shari'a Supervisory 
Hussein Elasrag

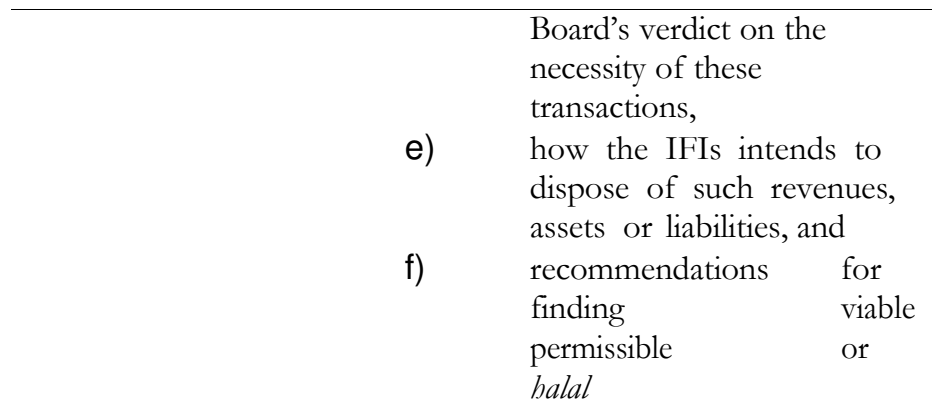

alternatives for similar impermissible transactions in the future. 
The procedure above should be read in conjunction with and supplements any existing AAOIFI standards that relate to earnings and expenditure prohibited by Shari'a (para 15).

\section{$5 / 2 / 4$}

Policy for employee welfare

IFIs shall implement a CSR policy for employee welfare. This policy shall stipulate provisions for the rights and obligations of employees, including provisions affording fair treatment of all employees, avoidance of discrimination, as well as expected behaviour of all employees. This policy may include specific provisions relating to:

a) equal opportunity for all employees, regardless of gender, race, religion, disability or socio-economic background,

b) merit-based salary and promotion structure for all employees, regardless of gender, race, religion, disability or socioeconomic background,

c) establishing long term incentive schemes and further development and training incentive schemes for all employees,

d) provisions for maternity leave and flexible work hours for female employees,

e) maximum allowable work hours under full-time, part-time and casual employment for all employees,

f) prohibition of discrimination, including and not limited to gender, race, religion, disability or socio-economic background, penalties for such discrimination and 
avenues for complaints for such discrimination without any manner of recrimination

(Appointment(s) should be made within the organization to deal with such discrimination; the person(s) appointed must be seen to be just and fair to all employees, regardless of the employee's gender, race, religion, disability or socio-economic background),

g) pro-actively establishing, monitoring and acting on realizable quotas/targets for employment of staff from disadvantaged backgrounds, with disabilities, from a minority group, and/or from underrepresented groups in the formal economy (including females) (affirmative action).

h) elimination of child labour from the workforce and if not feasible, educational and familial support for children,

i) elimination of class and race barriers between higher and lower ranking employees,

j) expected behavior of all employees in line with the Code of Ethics for the Employees of Islamic Financial Institutions,

k) expected behavior (humility, modesty and mutual respect) of higher ranking employees towards 
Corporate social responsibility:An Islamic Perspective

lower ranking employees, vice versa, and

I) occupational health and safety measures to be taken by the IFI and by the employees.

A policy disclosure must be made to all employees before commencement of the employment contract and preferably be disclosed in any form of media that is utilized to advertise employment vacancies. This policy disclosure should form part of the contractual terms and conditions. Efforts should be made to communicate this policy disclosure to all employees in their native language (language most frequently used by the employee) (para 16). 
The terms and conditions under which a Zakah policy must be established are stated in Shari'a Standard No. xx, Statement of Financial Accounting No. 2 Concepts of Financial Accounting for Islamic Banks and Financial Institutions section 4/6 and Financial Accounting Standard No. 9 on Zakah (para 17).

$5 / 3$ Recommended conduct 5/3/1 Policy for

\section{Qard}

\section{Hasan}

IFIs may implement a CSR policy for Qard Hasan for social reasons. The provisions of this policy may include matters pertaining to:

a) establishing a Qard Hasan fund,

b) maintaining a record of sources of Qard Hasan funding (depositors, shareholders and/or other parties) (sources of funds),

c) types of allowable beneficiaries of the Qard Hasan funds as determined by the bank (allowable uses of funds),

d) circumstances in which such loans are distributed to individuals (or to organizations),

e) contractual enforcement measures for debtors able to repay loans,

f) write off conditions for debtors unable to repay loans, and

g) developing a strategy to increase Qard Hasan loans from the sources referred to in $5 / 3 / 1 b$, which are to be used solely for 
charitable purposes, and pro-actively establishing, monitoring and acting on realizable quotas/targets for this particular strategy.

This policy may be monitored on a yearly basis. If implemented, this policy may supplement any provisions contained elsewhere in the AAOIFI standards including, Statement of Financial Accounting No. 2 Concepts of Financial Accounting for Islamic Banks and Financial Institutions section 4/7 (para 18).

\section{$5 / 3 / 2$}

Policy for reduction of adverse impact on the environment

IFIs may implement a CSR policy for reducing the impact of the IFI on the environment. The provisions of this policy may include matters pertaining to:

a) establishing organization wide guidelines on efficient and minimal usage of nonrenewable resources,

b) initiatives to educate employees to efficiently use non-renewable resources and increase use of renewable resources,

c) incentives and initiatives to find alternatives to non-renewable sources of energy and materials for operations (e.g. e-mail bank statements instead of paper bank statements), or

d) incentives and initiatives to recycle renewable sources of materials within the organization.

The provisions of this policy may be reviewed on a yearly basis to implement new and innovative methods by which to minimize the environmental impact of the IFI (para 19). 


\section{5/3/5 Policy for social, development and environment based investment quotas}

IFIs may implement CSR policies for social, development and environment based investment quotas. This policy may include provisions for pro-actively establishing, monitoring and acting on realizable and profitable investment quotas/targets, based on the extent to which the investments directly or indirectly contribute to social, development and environmental causes (para 20).

Social Impact Investments: These policies may include quotas/targets for social-impact investments, based on the role that the investments play in:

a) assisting poor and needy individuals and families, by financing business opportunities and/or education,

b) assisting orphans,

c) assisting heavily indebted individuals or families with unfortunate circumstances,

d) assisting in the provisioning of health and medical services to impoverished communities or areas,

e) assisting in the development of research and education facilities, particularly those that utilize and empower disadvantaged individuals or communities,

f) assisting the development of small and medium sized entrepreneurs and family businesses,

g) encouraging the development of Islamic and native societal culture, and

h) discouraging contemporary social ills and vices (para 21). 
Development Impact Investments: These policies may include quotas/targets for development impact investments:

a) that offer significant growth potential for the country of operation or for another developing country,

b) that significantly contribute to the development of infrastructure in the country of operation or for

c) that have a significant proportion of small to medium size enterprises (SME) or indirectly rely on small to medium size enterprises (SME), and/or

d) that directly or indirectly assists in the alleviation of social and economic disadvantages and discrimination, including and not limited to microfinance industry and thirdsector organizations (para 22).

Environmental Impact Investment: These policies may include quotas/targets for environmental impact investments, based on the role that the investments play in:

a) protecting the environment,

b) reducing the impact of development on the environment,

c) encouraging individuals and institutions to protect and preserve the natural environment and reduce the impact of development on the environment, and

d) increasing the use of renewable, sustainable 
Hussein Elasrag

sources of energy and/or reducing the reliance on

scarce non-renewable sources of energy (para 23). 
This policy may be monitored on a yearly basis, with revisions being made on based on quota/target performance (para 24).

$5 / 3 / 6$

Policy for par excellence customer

service

IFIs may implement a CSR policy to develop par excellence customer service skills of employees and contractors. The provisions of this policy may include matters pertaining to:

a) establishment of a code of conduct for all employees and contractors in dealing with customers (The code of conduct for customer service may include the provisions from the Code of Ethics for the Employees of Islamic Financial Institutions section 6/3),

b) active measures to be taken by management to develop customer service skills of employees, and

c) surveys that provide customer service feedback on performance/quality and likely areas of improvement (para 25).

$5 / 3 / 7$

Policy for micro and small business and social savings and investments

IFIs may implement a CSR policy to assist micro and small business and social savings and investments. The provisions of this policy may include matters pertaining to:
a) encouragement of micro and small business savings through special features and terms for these types of investment depositors,
b) encouragement of social savings for marriages, children's education,




\begin{tabular}{ll}
\hline & community based \\
& programs and other social \\
& welfare programs through \\
& special features and terms \\
& for these types of \\
& investment depositors, \\
& encouragement of both \\
& micro and small business \\
& savings and investment \\
& through combination \\
& features and terms for \\
& these types of investment \\
& depositors (for e.g. savings \\
& deposit with higher rates of \\
& return and investment loans \\
& discounts etc), and \\
& encouragement of both \\
& family savings and \\
& investment through \\
& combination features and \\
& terms for these types of \\
investment depositors (for & e.g. savings deposit with \\
higher rates of return and & investment loan discounts \\
& etc) (para 26). \\
&
\end{tabular}

IFIs may implement a CSR policy for charitable activities. The provisions of this policy may include matters pertaining to:

a) establishing a charity fund,

b) establishing avenues for voluntary donations by donors (e.g. from depositors, shareholders, clients, contractors and employees) for the charity,

c) establishing fund raising drives (emergency or otherwise) from bank's clients through existing operational means,

d) establishing target groups, communities and 
Corporate social responsibility:An Islamic Perspective

institutions that require assistance, including those described in policy for social impact based investment quota (section $5 / 3 / 4$ ) and policy for environmental impact based investment quotas (section $5 / 3 / 5)$

e) means by which charity may be distributed to prospective donees, and 


f)
establishing a trust
foundation to distribute
funds to allocated charities
(para 27).

\section{5/3/9 Policy for Waqf management}

IFIs may implement a CSR policy for managing $W$ aqf properties on behalf of their beneficiaries. The provisions of this policy may include matters pertaining to:

\begin{tabular}{|c|c|}
\hline a) & $\begin{array}{l}\text { establishing a Waqf } \\
\text { management department } \\
\text { or allocating staff to a } \\
\text { Waqf management function, } \\
\text { establishing rules and } \\
\text { guidelines based on Shari'a } \\
\text { for Waqf }\end{array}$ \\
\hline $\begin{array}{r}\text { lanagement, } \\
\text { c) }\end{array}$ & $\begin{array}{l}\text { establishing a fair rate } \\
\text { structure for the provision } \\
\text { of services by the bank, } \\
\text { and }\end{array}$ \\
\hline d) & $\begin{array}{l}\text { giving discounted rates } \\
\text { and flexible terms for } \\
\text { Waqf investment financing } \\
\text { (para 28). }\end{array}$ \\
\hline
\end{tabular}

\section{Disclosure requirements and presentation treatment options}

\section{6/1 Mandatory disclosure requirements}

Disclosure should be made, in a separate CSR report contained within the annual report, of the material policies of the IFI with respect to its mandatory CSR conduct to satisfy the information needs of the IFI's stakeholders. Disclosure may also be made in other reports specifically targeted towards the general public (para 29).

It should be noted that while disclosures are meant to be comprehensive, the potential user groups of CSR information are wide and hence disclosures should be designed with the intention of making them as understandable as possible for the general 
public (para 30).

\section{6/1/1 Disclosure of policy for screening clients}

Disclosure should be made, in the annual report, of the CSR policy on screening clients. This disclosure should stipulate

a) the specific provisions of the screening policy including the benchmarks and/or criterion utilized to measure compliance with Islamic law, and

b) whether these have been approved by the Shari'a supervisory board (para $31)$.

\section{6/1/2 Disclosure of policy for dealing with clients}

Disclosure should be made, in the annual report, of the CSR policy on dealing with clients. This disclosure should stipulate the specific provisions of the CSR policy including:

a) the defined procedure of the IFI on avoiding the imposition of onerous contractual terms on clients who are in a weaker bargaining position relative to the IFI,

b) the provisions ensuring that marketing campaigns and documents are ethically balanced,

c) the obligation and rights of both parties,

d) the due process and responsible terms and conditions under which credit is extended to clients, including the process by which the client's ability to repay and the effect on the client's financial and overall well-being is assessed, 


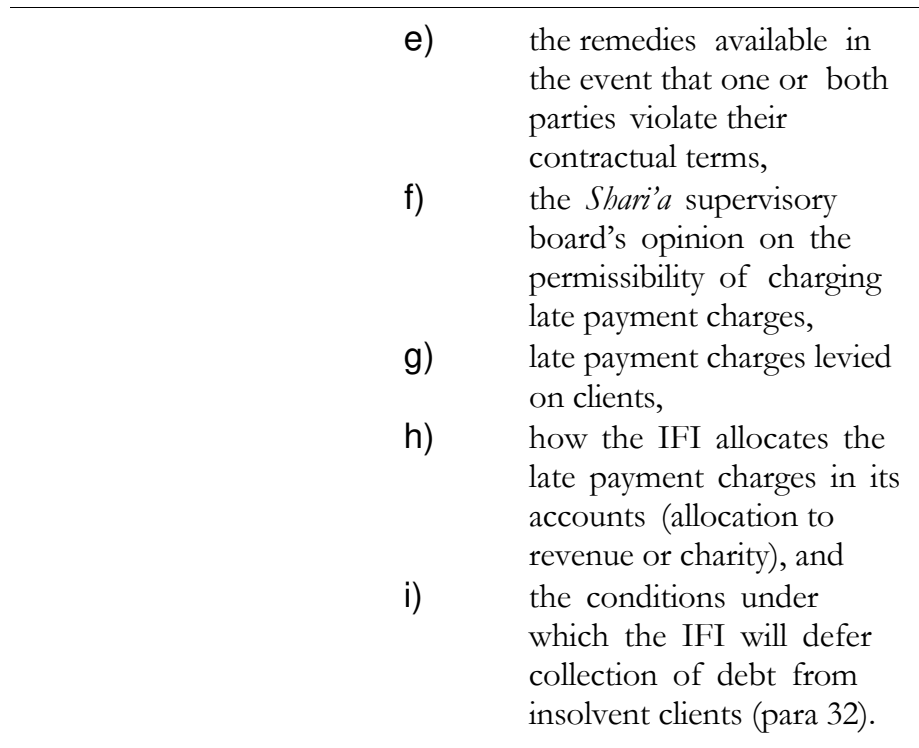

$6 / 1 / 3$

Disclosure of earnings and expenditure prohibited by Shari'a

Disclosure should be made, in the annual report, of the earnings and expenditure prohibited by Shari'a (impermissible or haram transactions) for the financial year, if any. This disclosure should stipulate the following items for the financial year:

a) Aggregate descriptions, amounts, account classification (revenue, expense, liability or asset) and reasons for undertaking the types of transactions,

b) The SSB's verdict on the necessity of these transactions,

c) How the IFI intends to dispose of such amounts,

d) The IFI's strategy to find viable permissible or halal alternatives, if any, for similar impermissible transactions in the future (para 33). 


\section{Corporate social responsibility:An Islamic Perspective}

This comprehensive disclosure supplements existing disclosure required by other AAOIFI standards (Financial Accounting Standard 1: General Presentation and Disclosure in the Financial Statements of Islamic Banks and Financial Institutions section 3/6) (para 34).

\section{6/1/4 Disclosure of policy for employee welfare}

Disclosure should be made, in the annual report, of the IFI's policy for employee welfare. This disclosure should stipulate the provisions of the IFI policy and the measures taken to implement these provisions within the organization (para 35).

The disclosure may include the policy relating to affirmative action, including:
a) provisions of the policy, including targeted disadvantaged groups,
b) quotas/targets and achievements for the year, and
c) reasons for upward and downward revisions in quotas/target.

This disclosure may be included with the mandatory disclosure of the policy for employee welfare.

\section{6/1/5 Disclosure of policy for Zakah}

Disclosure should be made for Zakah, in the financial statements, in accordance with the provisions of Financial Accounting Standard No. 9 on Zakah (para 36). 
Disclosure may be made of the material policies of the IFI with respect to its recommended CSR conduct to satisfy the information needs of the IFI's stakeholders. Disclosure may be made in other reports specifically targeted towards the general public (para 38).

It should be noted that while disclosures are meant to be comprehensive, the potential user groups of CSR information are wide and hence disclosures should be designed with the intention of making them as understandable as possible for the general public (para 39).

\section{6/2/1 Disclosure of policy for social, development and environment based investment quotas}

Disclosure may be made, in the annual report, of the CSR policy for social, development and/or environment based investments quotas and the extent of implementation of this policy for the financial year. The disclosure may include:

a) the provisions of the policy,

b) classes of investments by ultimate purpose/beneficiary of investments (e.g. orphans, SME development, Islamic culture, reduction in tree logging, reduction in environmental greenhouse gases, increase in recycling, science and technology)

c) the profitability of such investments for the year,

d) quotas/targets and achievements for the year, and

e) reasons for upward and downward revisions in quotas/target (para 40).

\section{6/2/2 Disclosure of policy for par excellence customer service}

Disclosure may be made, in the annual report, of the CSR policy for par excellence customer service. The disclosure may include: 
Corporate social responsibility:An Islamic Perspective

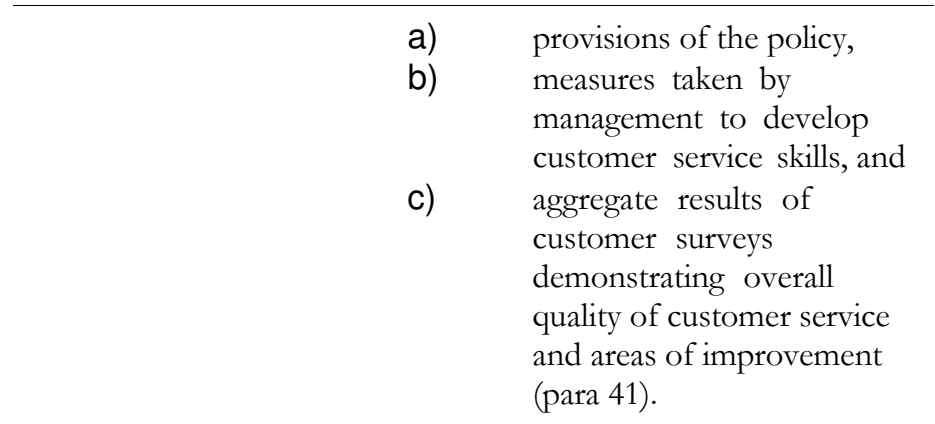

$6 / 2 / 3$

Disclosure of policy for micro and small business and social savings and investments

Disclosure may be made, in the annual report, of the CSR policy for micro and small business and social savings and investments. The disclosure may include:

a) provisions of the policy,

b) features of the offer,

c) measures taken by management to implement the provisions of the policy,

d) quotas/targets and achievements for the year, and

e) reasons for upward and downward revisions in quotas/target (para 42).

\section{6/2/4 Disclosure of policy for Qard Hasan}


Disclosure may be made, in the annual report, of the CSR policy for

Qard Hasan. The disclosure may include:

a) whether there is a formal scheme operated by the bank for depositors, shareholders and other parties to place their funds for the use of Qard Hasan borrowers,

b) provisions of the policy/scheme including conditions for those unable to repay the loans,

c) sources of funding for Q Qard Hasan loans,

d) aggregate purposes for which the Qard Hasan loans have been made,

e) quotas/targets to increase internal and external Qard Hasan

funding and achievements for the year in this regard, and

f) reasons for upward and downward revisions in quotas/target.

The disclosure requirement should be read in conjunction with and supplements any disclosure recommended by the existing AAOIFI Statement of Financial Accounting No. 2 Concepts of Financial Accounting for Islamic Banks and Financial Institutions section 4/7 and Financial Accounting Standard 1: General Presentation and Disclosure in the Financial Statements of Islamic Banks and Financial Institutions section 4/7 (para 42).

\section{7/2/5 Disclosure of policy for charitable activities}

Disclosure may be made, in the annual report, of the CSR policy for charitable activities. The disclosure may include:

a) provisions of the policy,

b) aggregate classes of charitable activities by 
ultimate beneficiary and amounts distributed to each aggregate class,

c) quotas/targets and achievements for the year, and

d) reasons for upward and downward revisions in quotas/target.

This disclosure will supplement any disclosure recommended by the existing AAOIFI Statement of Financial Accounting No. 2 Concepts of Financial Accounting for Islamic Banks and Financial Institutions section 4/6 and Financial Accounting Standard No. 9 Zakah (para 43).

\section{7/2/11 Disclosure of policy for Waqf management}

Disclosure may be made, in the annual report, of the CSR policy for

Waqf management. The disclosure may include:

a) types of $W$ aqf managed by the IFI,

b) financial and other services offered to the Awqaf by the IFI (para 44).

\section{Responsibility under this standard}

\section{7/1 Compliance and attestation function}

It is the responsibility of the Board of Directors to ensure compliance with the provisions of this standard and provide an independent attestation of CSR conduct as an assurance to stakeholders (para 45). 
The compliance function will comprise testing whether the mandatory and recommended CSR conduct provisions of this standard are implemented both in form and in substance by the IFI (para 46).

The attestation function will comprise signing off by the board of directors or its main representative on the CSR report provided by management. The attestation may include:

a) providing a statement which stipulates that management has proactively engaged in the mandatory and voluntary provisions of the CSR standard in all its conduct, and/or,

b) providing a statement which stipulates that management's representations in the annual report regarding its CSR conduct fairly represent management's actual conduct (para 47).

\section{$7 / 2$}

Implementation function

The responsibility for implementation of this standard lies with the management of an IFI (para 48).

\section{Effective Date}

This standard shall be effective for financial periods beginning (Arabic Date) or (English Date) (para 48). 


\section{Appendix B: Reasons for the standard}

The reason for this standard is to provide specific guidance to IFIs to engage in productive CSR activities and disclose the nature of these activities to their stakeholders. Since there is no comparable standard generally and specifically for IFIs, this is an important standard to ensure the legitimacy and reputation of IFIs are preserved.

The rationale for this standard stems from the significant variation in the practice and understanding of CSR by IFIs. A number of research papers indicate that IFIs have widely varying CSR practices, with some IFIs really delivering high quality CSR initiatives and reports, whereas other IFIs are simply not interested in CSR. The papers also suggest that CSR activities are misunderstood as any activity that is not directly aligned with profit incentives. As a result, a number of IFIs engage in supporting activities that are not within the definition of social responsibility as espoused by Islamic scholars and thinkers. Rather, they are perceived to be marketing ploys to enhance the reputation of the IFI, with little direct social or environmental improvement.

The Islamic perspective on social responsibility is that the activities must directly assist individuals or societies to enhance their living or environmental conditions or assist them to better comply with religious rules and norms. Islam discourages the boasting of socially responsible activities to enhance one's own image. However, this does not necessarily imply that institutions representing stakeholders shouldn't be accountable. Indeed, Islam encourages accountability and therefore IFIs should be held accountable by their stakeholders for the extent of engagement ir social activities. 


\section{Appendix C: Basis for conclusions}

CSR derives itself from core principles in the Holy Qur'an. The three major foundational principles for CSR are the vicegerency of mankind on earth, divine accountability and the duty on mankind to enjoin good and forbid evil.

\section{Vicegerency}

The principle of vicegerency denotes that mankind is the representative of Allah on earth and as such Allah has entrusted mankind with stewardship of Allah's possession. Allah states this principle in the Qur'an: I will create a vicegerent on earth ${ }^{2}$; and Allah further states: It is he who hath made you the inheritors of the earth, ${ }^{3}$

\section{Divine Accountability}

The principle of divine accountability flows from the vicegerency principle and denotes that individuals will be accountable to Allah for all of their actions on the Day of Judgment. This principle is expounded in several verses of the Qur'an, two of which are: Allah takes careful account of everything, ${ }^{4}$ and Then shall anyone who has done an atom's weight of good shall see it and anyone who has done an atom's weight of evil, shall see it. ${ }^{5}$ This divine accountability is the basis for all actions of a Muslim ${ }^{6}$, and in turn the representative organizations of Muslims.

\section{Enjoining good and forbidding evil}

The principle of enjoining good and forbidding evil encapsulates the responsibilities that Allah places on Muslims as trustees and vicegerents. Allah says that: The Believers, men and women, are protectors one of another; they enjoin what is just (accepted), and forbid what is unjust (rejected)... ${ }^{7}$ and in another verse, Allah states: You are the best of peoples,

evolved for mankind, enjoining what is just (accepted), forbidding what is unjust (rejected), and believing in Allah ${ }^{8}$. This responsibility is overwhelming and encompasses all aspects of a Muslim's life. It comprises a prescription towards positive (permissible and

recommended) actions and a prescription against negative (impermissible and not recommended) actions. IFIs have generally ensured their operational status by avoiding negative actions. However, their approach to positive actions has been varied due to a lack of standards in the area. 
The combination of these principles denotes a divine accountability for each Muslim to enjoin good and justice and forbid evil and injustice. These core principles therefore constitute the basis of individual social responsibility.

\section{Collective religious duty and Islamic Financial Institutions}

IFIs came into existence as a collective religious obligation (Fard Kifayah) $)^{9}$ on the larger

community (Ummah). This obligation is to operate a financial intermediary for individuals in the larger community wishing to comply with Islamic law (Shari'a). In this special position, IFIs are able to perform the obligations that individuals cannot perform themselves. The IFIs are therefore representatives for individuals who:

i. invest their money as shareholders or investment account holders,

ii. have co-operative, partnership or borrowing relations with the IFI,

iii. are employed by the IFI,

iv. have other explicit contractual relations with the IFI,

Surat Al Baqarah (The Heifer) verse 30.

Surat Al Ana'm (Cattle) verse 165.

Surat Al Nisa (Women) verse 86.

Surat Al Zalzala (The Earthqyake) verse 7-8)

One who submits to the will of Allah.

Surat Tawba (The Repentance), verse 71.

Surat Al-e-Imran (The Family of Imran) verse 110.

Fard Kifayah refers to a collective religious duty which, if performed by some, would exempt others from performing it. However, if it is not performed by any, the entire community is sinful. 
v. in addition to the above, have a implicit social contract with the IFI as part of the larger community (Ummah).

Second, IFIs, hold a position of significant responsibility in society as financial intermediaries which source and allocate funds. The example set by IFIs has an impact on other individuals, institutions and organizations.

These two points denote that IFIs are a fard kifayah. ${ }^{10}$ It is therefore pertinent that IFIs play a role in encouraging the right type of behavior and activities while discouraging the wrong type of behavior and activities.

\section{Islamic Corporate Social Responsibility}

The core foundations of CSR are the same as the foundations for individual social responsibility of each Muslim: to enjoin right and to forbid wrong. The definition of right and wrong in Islam can be defined in various dichotomies which are overlapping. In their legal form, right refers to everything that is permissible or recommended (Halal and Mustahab respectively), while wrong refers to everything that is impermissible or not recommended (Haram and Makerub respectively). From the perspective of Islamic jurisprudence, right refers to what is just while wrong refers to what is unjust.

However, because IFIs are a collective religious obligation (Fard Kifayah), the definition of right and wrong are sometimes of a different nature than those that apply to individuals. This is because IFIs have a special religious and financial position in society.

Religiously, IFIs have a responsibility to comply with the form and substance of Islamic law in all aspects of their operations. This is because they are in an exemplary position. This means that all aspects of its operations should be conducted in a permissible or recommended manner while no aspect of its operation should be conducted in an impermissible or not recommended manner. If it is conducted in an impermissible or not recommended manner, it is an obligation to disclose to its stakeholders the reasons for that particular conduct.

Financially, IFIs are intermediaries which mobilize funds from investors and allocate funds to projects and other investments. In this context, it is the responsibility of IFIs to mobilize funds 
from permissible and recommended sources and invest funds in permissible and recommended projects. Further, IFIs are also in an exemplary position as financial intermediaries and hence can significantly impact the conduct of the IFIs stakeholders.

\section{Mandatory and Recommended Conduct Classifications}

The classification between mandatory and recommended conduct is based on the Qur'anic principle of not imposing responsibilities on individuals (and in extension organizations) by Allah greater than what they can endure: On no soul doth Allah Place a burden greater than it can bear. ${ }^{11}$

10 Fard Kifayah refers to a collective religious duty which, if performed by some, would exempt others from performing it. However, if it is not performed by any, the entire community is sinful.

Surat Al Baqarah (The Heifer) verse 286. 


\section{Appendix E: Definitions}

\section{Clients}

Clients in this standard are defined as those individuals who and corporations which execute a sale, lease, borrowing or partnership agreement with the IFI. This does not include Investment Account Holders or depositors of any type.

\section{Contractors}

Contractors in this standard are defined as businesses or corporations who provide services to the IFI in return for a contractually agreed consideration. Contract workers are differentiated from employees because they do not have a direct contractual relationship with the IFI.

\section{Customers}

Customers in this standard are defined as all individuals and institutions that execute any type of contract in which the Islamic bank provides a good or service in return for valuable consideration.

\section{Deposit customers}

Deposit customers in this standard are defined as those individuals and institutions which execute a contract to place funds with the IFI for safe keeping, deposit or investment. This does not include shareholders of any type.

\section{Employees}

Employees in this standard are defined as individual who work directly for the IFI in return for valuable consideration. This includes all ordinary connotations of the word employee including full-time, part-time, casual, seasonal, contract and project based employment. Employees do not include contract workers working for a business or corporation other than the IFI. Employees are differentiated from contract workers because employees have a direct contractual relationship with the IFI, whereas contract workers do not have a direct contractual relationship with the IFI.

\section{Investment Deposits}


Corporate social responsibility:An Islamic Perspective

Investment deposits in this standard are defined as deposits placed by customers for the purposes of gaining an investment rate of return, and not for the sole purpose of safe keeping. These include investment account holders.

\section{Investment Assets}

Investment assets in this standard are defined as those assets that bring a future economic benefit invested in by the IFI for the direct purpose of gaining a return and not for an operational purpose (e.g. fixed assets).

\section{Qard Hasan}

Qard Hasan in this standard is defined as a non-interest bearing loan intended to allow the borrower to use the loaned funds for a period of time with the understanding that the same amount of the loaned funds would be repaid at the end of the period.

\section{Waqf}

Waqf (plural Awqäf) in this standard is defined as an inalienable religious endowment in Islam. 


\section{Hussein Elasrag}

\section{Zakah}

Zakah is a fixed religious obligation calculated by reference to net assets (including cash) that have appreciated or have the capacity to appreciate in value over a specific period of time except for assets that have been acquired for consumption or use in the production of revenues. Zakah is a religious obligation on wealth for every Muslim, including a child or an insane person, must meet provided his net assets are liable for Zakah. 


\section{Appendix F: Examples of disclosure format and presentation}

\section{Notes:}

The purpose of this example is to illustrate the application of some of the provisions of this standard. The example is not intended to illustrate the only acceptable method for the presentation of or the disclosure of CSR activities and compliance. Furthermore, the example does not reflect all the requirements of the standard.

It should be noted that while disclosures are meant to be comprehensive, the potential user groups of CSR information are wide and hence disclosures should be designed with the intention of making them as understandable as possible for lay people.

The disclosures may be supplemented, if possible, with images of the tangible benefits resulting from CSR activities and compliance. 


\section{Exhibit A: Example of Comprehensive CSR Report}

In the Name of Allah, The Beneficient, The Merciful

\section{(Name of Bank or Institution) \\ Islamic Corporate Social \\ Responsibility Report For the year \\ ended $\mathrm{xxx}$}

(Name of Bank or Institution) is engaged in implementing ideals of Islamic Social Responsibility to the best of its ability in all aspects of its operations. In line with these ideals, Name of Bank or Institution) has applied best practice standards on Islamic Corporate Social Responsibility issued by the Accounting and Auditing Organization for Islamic Financial Institutions.

These standards stipulate mandatory and recommended forms of Islamic Corporate Social Responsibility activities and compliance. (Name of Bank or Institution) has implemented both mandatory and recommended forms of Islamic Corporate Social Responsibility.

The implementation of these standards in true Islamic form and substance by the management of (Name of Bank or Institution) is attested by the board of directors in its report to shareholders. Presented below is a summary of the compliance and initiatives undertaken by (Name of Bank or Institution) during the year ended xxx.

\section{Social Responsibility within the organization}

\section{Employee Welfare}

[State policy and affirmative action initiatives for employee welfare here]

\section{Internal Environmental Preservation Policy}

[State policy for reduction of environmental impact and initiatives, targets and achievements for the year here]

Earnings and expenditure probibited by the Shari'a 
Corporate social responsibility:An Islamic Perspective

[State policy for impermissible transactions and detailed information for the year here]

Social Responsibility in its relationship with customers and clients

Par Excellence Customer Service

[State policy for customer service, initiatives, targets, achievements and survey results for the year here]

Late Repayments and Insolvent Clients and avoiding onerous terms

[State policy for late repayments and insolvent clients and avoiding onerous terms here]

Qard Hasan

[State policy for Qard Hasan and detailed information for the year including beneficiaries of Qard Hasan here]

Special features 
[State policy on encouragement of entrepreneur and social savings and investments here and initiatives, targets and achievements for the year here]

\section{Social Responsibility in screening its investments}

Screening of clients for compliance with Islamic principles and social responsibility

[State policy on screening of clients and contractors here]

Investment quotas based on industry, social impact and environmental impact

[State policy on investment quotas and initiatives, targets and achievements for the year here]

\section{Social Responsibility in its relationship with greater society}

\section{Zakah}

[State policy on Zakah and detailed information about Zakah for the financial year here]

\section{Charitable activities}

[State policy on charitable activities and detailed information on charitable activities for the financial year here]

Waqf Management

[State policy on $W$ aqf management here and detailed information on types of Awqaf managed, services offered to Awqaf, and initiatives for the financial year here] 


\section{References}

AAOIFI. (n.d.). Governance Standard for Islamic Financial Institutions No. 7 Corporate Social Responsibility Conduct and isclosure for Islamic Financial Institutions: Accounting and Auditing Organization For Islamic Financial Institutions (AAOIFI).

Ali Aribi, Z., \& Gopinath Arun, T. (2012). Corporate Social Responsibility in Islamic Financial Institutions (IFI): A Management Insight. Available at SSRN 2052635.

Allen\&OveryLLP. (2009). Islamic microfinance report for institutions offering Islamic financial services.

Arsad, S., Ahmad, R., Fisol, W. N. M., Said, R., \& Haji-Othman, Y. (2015). Maqasid Shariah in Corporate Social Responsibility of Shariah Compliant Companies. Research Journal of Finance and Accounting, 6(6), 239-247.

Ayub, M. (2009). Understanding Islamic Finance: Wiley.

Brown, D. (2013). Corporate social responsibility. (A Senior Thesis submitted in partial fulfillment of the requirements for graduation in the Honors Program), Liberty University.

Dewar, J., \& Hussain, M. M. (2011). ISLAMIC PROJECT FINANCE. In J. Dewar (Ed.), International Project Finance: Law and Practice: OUP Oxford.

Farook , S. (2007). On corporate social responsibility of Islamic financial institutions. Islamic Economic Studies, 15(1), 31-46.

Friedman, M. (1962, 1982). Capitalism and freedom. United States of America: University of Chicago press.

Friedman, M. (September 13, 1970). The Social Responsibility of Business is to Increase its Profits. The New York Times Magazine.

Haniffa, R., \& Hudaib, M. (2007). Exploring the ethical identity of Islamic banks via communication in annual reports. Journal of Business Ethics, 76(1), 97-116.

Hassan, A., \& Latiff, S. B. A. (2009). Corporate social responsibility of Islamic financial institutions and businesses: Optimizing charity value. Humanomics, 25(3), 177-188.

Hidayati, N. D. (2011). Pattern of corporate social responsibility programs: a case study. Social Responsibility Journal, 7(1), 104-117.

Hossain, M. T. B., \& Siwar, C. (2009). A Comparative Analysis Between Islamic Concept On Corporate Social Responsibility And Malaysia Mangers Opinion. Management of Environmental Quality: An International Journal, 20(3), 290-298.

Jamali, D., \& Mirshak, R. (2007). Corporate social responsibility (CSR): theory and practice in a developing country context. Journal of Business Ethics, 
72(3), 243-262.

Maali, B., Casson, P., \& Napier, C. (2006). Social reporting by Islamic banks. Abacus, 42(2), 266-289.

Mohammed, J. A. (2007). Corporate social responsibility in Islam. Auckland University of Technology.

Mohammed, J. A. (2013). AN ISLAMIC PERSPECTIVE OF CORPORATE SOCIAL RESPONSIBILITY. The Global Conference on Business, Economics and Social Sciences Research (GBSR).

Moon, J. (2011). Corporate Social Responsibility. Manchester Business School.

Othman, A., \& Mia, B. (2008). Corporate social responsibility for solving the housing problem for the poor in South Africa. Journal of Engineering, Design and Technology, 6(3), 237-257.

Othman, A. A. E. (2009). Corporate social responsibility of architectural design firms towards a sustainable built environment in South Africa. Architectural Engineering and Design Management, 5(1-2), 36-45.

Radwa, S. (2011). Corporate Social Responsibility in Islamic Law: Labor and Employment. Yonsei Law Joumal, 2(1), 65-92.

Shamim, M., \& Karim, N. (2010). Corporate Social Responsibility: Contemporary Thought and Islamic Perspectives. Thoughts on Economics, 21(1), 45-66.

Tanimoto, K. (2007). Corporate social responsibility and public policy. Paper presented at the ADBI CONFERENCE: ENHANCING CORPORATE SOCIAL RESPONSIBILITY IN ASIA.

Uusmani, M. T. (2002). An introduction to Islamic finance (Vol. 20): Brill.

Wajdi Dusuki, A. (2008). What does Islam say about corporate social responsibility? Review of Islamic Economics, 12(1), 5-28.

Zain, M. M., Darus, F., Yusoff, H., Amran, A., Fauzi, H., Purwanto, Y., \& Naim, D. M. A. (2014). Corporate ibadah: an Islamic Perspective of Corporate Social Responsibility. Middle-East Journal of Scientific Research, 22(2), 225-232.

UK Essays. Corporate Social Responsibility [Internet]. November 2013. [Accessed 10 July 2014]; Available from: http://www.ukessays.com/dissertations/sociology/corporate-socialresponsibility.php?cref $=1$.

UK Essays. Corporate Social Responsibility [Internet]. November 2013. [Accessed 10 July 2014]; Available from: http://www.ukessays.com/dissertations/management/corporatesocial-responsibility.php?cref $=1$.

Essays, UK. (November 2013). The Concept Of Corporate Social Responsibility Csr Shareholders Essay. Retrieved from http://www.ukessays.com/essays/business-stakeholders/theconcept-of-corporate-social-responsibility-csr-shareholders- 
Corporate social responsibility:An Islamic Perspective essay.php?cref $=1$ 

